\title{
Environmental Offset Programs: Survey and Synthesis
}

Link to publication record in Manchester Research Explorer

\section{Citation for published version (APA):}

Hahn, R., \& Richards, K. (2010). Environmental Offset Programs: Survey and Synthesis.

http://www.sci.manchester.ac.uk/

\section{Citing this paper}

Please note that where the full-text provided on Manchester Research Explorer is the Author Accepted Manuscript or Proof version this may differ from the final Published version. If citing, it is advised that you check and use the publisher's definitive version.

\section{General rights}

Copyright and moral rights for the publications made accessible in the Research Explorer are retained by the authors and/or other copyright owners and it is a condition of accessing publications that users recognise and abide by the legal requirements associated with these rights.

\section{Takedown policy}

If you believe that this document breaches copyright please refer to the University of Manchester's Takedown Procedures [http://man.ac.uk/04Y6Bo] or contact uml.scholarlycommunications@manchester.ac.uk providing relevant details, so we can investigate your claim.

\section{OPEN ACCESS}


Sustainable

Consumption

Institute

\section{Environmental Offset Programs: Survey and Synthesis}

Robert Hahn and Kenneth Richards

June 2010

Revised: November 18, 2010

Sustainable Consumption Institute

The University of Manchester

188 Waterloo Place

Oxford Road

Manchester M13 9PL

Tel: $+44(0) 1612754030$ 


\title{
Environmental Offset Programs: Survey and Synthesis
}

\author{
Robert Hahn and Kenneth Richards*
}

June 2010

Revised: November 18, 2010

Prepared for submission to the Review of Environmental Economics and Policy

\footnotetext{
* Robert Hahn is professor of economics and director of the Sustainable Consumption Institute at the University of Manchester; a senior visiting fellow at the Smith School, University of Oxford; and a senior fellow at the Georgetown Center for Business and Public Policy. Kenneth Richards is an associate professor of environmental and energy policy and law at the School of Public and Environmental Affairs; Associate Director at the Lugar Center for Renewable Energy, and the James Martin Senior Visiting Fellow at the Oxford Martin School, University of Oxford. We would like to thank Don Carr, Michael Grubb, Dieter Helm, Al McGartland, Axel Michaelowa, Janet Peace, John Palmisano, Ian Parry, Rob Stavins, Tom Tietenberg, Alexander Vasa and David Victor for helpful suggestions. Emily Giovanni, Tengbo Li, Martin Mattsson, Stephanie Richards, and Kelley Weddell provided valuable research assistance. The views expressed in this paper reflect those of the authors and do not necessarily reflect those of the institutions with which they are affiliated. (C) 2010 by the authors. All rights reserved.
} 


\begin{abstract}
In the real world, taxes and cap-and-trade systems are rarely implemented in their pure form. In this paper, we examine a related approach that has been used widely in practice - which we refer to as an "offset." The idea behind offsets is to encourage firms or entities that may not be a part of the main regulatory system to produce environmental improvements, which can then be used to offset pollution reduction requirements in the main regulatory system.

This paper provides a survey and synthesis of the literature on the use of offsets. Examples include offsets for limiting greenhouse gas emissions, maintaining ecosystem services for wetlands, achieving local air pollution goals, protecting water quality, and promoting energy efficiency. The paper reviews how offsets are used in practice and examines what is known about their environmental and economic impacts.

Combining insights from the political economy of using offsets with their intrinsic design challenges raises a potentially serious problem - namely, that offsets may often fail to take adequate account of environmental or ecosystem damages. Because this problem can be significant, alternatives should be considered.
\end{abstract}




\title{
Environmental Offset Programs: Survey and Synthesis
}

\author{
Robert Hahn and Kenneth Richards
}

\section{Introduction}

One of the great ideas invented by economists was to suggest using "market mechanisms" to achieve a given environmental outcome at least cost (Pigou 1920; Crocker 1966; Dales 1968). The two textbook examples most often presented in economics classes are taxes and cap-and-trade. Taxes are an example of a pricing instrument and cap-andtrade is a quantity instrument. Both of these instruments work by putting a price on pollution, thus encouraging those firms with the least expensive pollution control options to make use of them.

In the real world, taxes and cap-and-trade systems are rarely implemented in their pure form (Hahn 1989). In this paper, we examine a related approach that has been used widely in practice - which we refer to as an "offset." A key goal of an offset program is to reduce the costs of achieving a particular level of environmental protection. The costs include not only compliance costs, but the additional private transactions costs and public administrative costs associated with the offset program.

The idea behind offsets is to get firms or entities that may not be a part of the core regulatory system to produce environmental improvements, which can then be used to offset pollution reduction requirements in the core regulatory system (Liroff 1980). So, for example, if a developer's activities take away wetlands in one neighborhood, he may be required to provide an equivalent amount of wetlands, or eco-system services in another area.

In principle, offsets, like other market mechanisms, have the potential to dramatically lower the costs of achieving a given environmental quality target. For example, U.S. Environmental Protection Agency analysis (EPA 2009) of the 2009 Waxman-Markey climate bill ${ }^{1}$ indicated that the abatement cost associated with the bill would be 20 percent higher if international offsets had not been incorporated-raising the cost of compliance over the years 2012 to 2050 by more than $\$ 518$ billion. Indeed, that bill allows up to two billion metric tons (in carbon dioxide equivalents) of offsets per year, enough to cover all of the reductions required by the bill for many years.

This paper provides a survey and synthesis of the growing literature on the use of offsets. We review the rich array of applications of offsets in environmental and energy regulation. Examples are drawn from offset programs for limiting greenhouse gas emissions, maintaining ecosystem services for wetlands, achieving local air pollution goals, water quality protection, and promoting energy efficiency. The paper will review how offsets are used in practice and examine what is known about their environmental and economic impacts. In addition, it will compare how the design of offset programs compares along a number of key dimensions. To the extent that the data permit, we will evaluate the effectiveness of offset programs. We will also examine reasons that decision makers appear to have embraced offsets as a regulatory tool.

\footnotetext{
${ }^{1}$ American Clean Energy and Security Act of 2009, 111 H.R. 2454.
} 
We find that while offsets may be theoretically attractive in certain situations, there are many obstacles to their effective implementation. In general, there is a tradeoff between the certainty of achieving additional environmental protection, on the one hand, and the potential to lower the cost of regulation, on the other. The nature of the tradeoffs and the benefits of developing environmental offset programs depend on the context in which they are developed. Notwithstanding the difficulties in applying offsets, it appears that they will continue to have considerable political support in some contexts. We offer some reasons why politicians have supported this idea in the past and will likely continue to do so.

\section{Defining and Evaluating Offsets}

Environmental offsets have been discussed broadly in the literature, but without a particular focus on this instrument (e.g., Stavins, 2003). Some sources focus on offsets in the context of EPA's air emissions trading program started in the 1970's (e.g., Hahn and Hester 1989; Liroff 1986; Tietenberg 2006), where offsets are described as a mechanism to allow new sources of criteria air pollutants in nonattainment areas "provided they acquire sufficient emission reduction credits from existing sources" (Tietenberg 2008).

Another part of the literature considers a much broader range of offsets, but with a less clear definition of the concept. For example, the Western Australia Environmental Protection Agency (2006) issued a position statement on environmental offsets that never defined the term offset. The Victoria State EPA (2008) vaguely defines an offset as an action to "address an adverse environmental impact of resource use, a discharge, emission or other activity at another location to deliver net environmental benefit."

We suggest that the focus on U.S. EPA's emissions trading program produces too narrow a conception of environment offset programs. At the same time, many definitions are not specific enough to provide the basis for a systematic examination of regulatory offsets.

We examine several programs that are developed in conjunction with specific environmental regulations, either at the domestic or international level. Purely voluntary offset programs, such as those offered to travelers by airlines to offset their carbon emissions, are not included in our discussion because they are not formally connected to the core regulatory program through a law or regulation. Furthermore, there is very little information about whether such programs actually result in emission reductions.

An environmental offset program is often associated with some form of regulation, which we call a core regulation. The core regulation could range from a command-and-control system to a cap-and-trade system. It constrains the activities of the covered parties, inducing them to engage in costly environmental protection activities. Generally, as a regulation becomes more stringent, the cost of each additional increment of environmental protection rises, which implies increasing marginal costs. An efficient policy would set marginal costs equal to marginal benefits.

Suppose now that there are other external activities that are not covered by the core regulation that, if implemented, would have the effect of promoting the same, or other, environmental goals. Suppose also that at least some of these activities outside the core regulation are less costly to implement. Clearly, if outside activities can be substituted for some of the more costly core activities, then the overall cost of meeting any environmental protection goal can be reduced. This leads to a lower marginal cost of compliance and a lower total compliance cost to achieve the same level of environmental protection. Ideally, the program will encourage private parties to undertake all offset activities that are lower cost than core activities, up to the point 
where the marginal cost of core activities and offset activities are equal. This discussion provides a basis for a definition of an offset policy instrument:

An offset instrument is an addition to a core regulatory program that allows entities that are regulated under the core program to meet a portion of their obligations through environmental improvements that take place outside of the core. The offset activity is supposed to provide an environmental benefit at least as large in value as the environmental damage caused by the relaxation in the core program. The offset activities can be carried out by the regulated party, another private party or a government entity.

Note that under this definition, a pure cap-and-trade system or emission tax would not involve an offset instrument because all sources would be covered by the core regulation. However, offset provisions could be added, as they were in the Waxman-Markey proposed legislation to curb U.S. carbon dioxide emissions.

The core regulation in this definition covers a well-defined set of activities, habitats, or emissions sources. In contrast, the parties that could provide offsets may not be easily identified in advance. Thus, under a wetlands mitigation program, the regulated wetlands are well defined. A developer can gain permission for an otherwise prohibited destruction of wetlands by creating a wetland of equal or greater value in an alternative location from land that is not controlled under the wetlands regulations. Similarly, a point source emitter of water pollution can earn credits that allow increased point source emissions by arranging for an otherwise unconstrained nonpoint source emitter to make reductions in pollution.

Under our definition, some environmental programs are actually offset systems, even though they have not traditionally been recognized as such. For example, we would include wetlands mitigation banking programs and point-nonpoint source water pollution trading programs. At the same time, one of the best recognized offset programs, the U.S. EPA's New Source Review offset provisions, actually is not an offset program using our definition because the only sources of offsets were controlled under the core regulation. At the same time, other programs, such as those involving transferable development rights, may not represent offset programs under our definition because the core regulation covers all sources of development. ${ }^{2}$

A critical question is how to evaluate the performance of an offset program. This involves setting a benchmark for comparison. Two benchmarks appear to be considered in the literature: First, comparing the offset policy to a situation in which there is no offset policy, but there is still a core regulatory program; and second, comparing an offset program to a situation in which there is a well-defined market-based program, such as cap-and-trade or taxes.

Note that using a benchmark of no-offset policy could lead to improvements in environmental quality and/or reductions in costs. In contrast, comparing an offset program to a full-blown capand-trade program that is functioning well will likely lead to the result that the offset program is more costly to administer, and quite possibly worse in environmental terms because offset programs generally fail to put clear boundaries around regulated activities.

\footnotetext{
${ }^{2}$ An alternative definition might define offset policies in terms of whether they require the specification of a counterfactual on a case-by-case basis to determine the "additional" improvements in environmental quality (e.g., see Stavins 2003). That definition would lead to a larger number of programs being included as offset instruments, but would not materially change the qualitative conclusions reached in this paper.
} 
It is important to consider indirect as well direct costs and benefits of offset programs in evaluating them. Two important indirect costs of offset programs that have received little attention in the literature are the deadweight costs associated with revenue loss and the potential costs of subsidizing an activity. If an offset program decreases revenues going to the government, say because an offset replaces revenues from an emissions tax or the auctioning of an allowance, then the deadweight loss associated with raising the revenue from somewhere else needs to be taken into account. This cost could be on the order of $\$ .30$ for each $\$ 1$ of lost revenue (Goulder 1999; Parry and Bento 2000). In addition, to the extent that offsets represent a subsidy to pollution generating activities, they can encourage inefficient entry into particular industries (Baumol and Oates 1988). To our knowledge, these costs have not been estimated. It is possible, that after accounting for the welfare impacts associated with revenue losses, offsets may fail to pass a benefit-cost test (e.g., Parry and Oates 2000).

Some scholars suggest that there are significant indirect benefits of offsets as well. One possible benefit is that offset policies have served as a stepping stone to the use of more efficient market-based approaches, such as the allowance trading system to reduce sulfur dioxide emissions in the U.S. This is plausible, but difficult to evaluate. For example, industry may have become more supportive of market-based approaches as experience was gained (Haddad and Palmisano, 2001). A second indirect benefit is that offsets, by subsidizing certain technologies, may give a boost to the development of these technologies. As we shall discuss below in the context of the Clean Development Mechanism, these benefits need to be weighed carefully against the costs. Our bottom line is that offsets generally represent an inefficient way of providing subsides for particular kinds of energy sources such as renewables because that is not usually their primary objective.

\section{Design Challenges and Possible Solutions}

The design of an environmental offset program entails several critical elements. The type and extent of the challenges varies from application to application. To implement an offsets program, it is necessary to (1) determine the basis for identifying equivalency between the environmental impacts of the regulatory relaxation and the offset effort (2) develop an ex ante offset certification process for certifying credits, including the timing of rewards, (3) identify the dimensions and unit of measure for the environmental tradeoff (e.g., metric tons of emissions, acres of land), (4) determine the type(s) of reference cases (baselines) that offsetters will be allowed or required to use, (5) determine the ex post monitoring requirements, (7) choose a trading ratio for the exchange between offset credits and regulatory relief, and (8) choose a form of reward (e.g., additional allowances, relief from a regulation).

A key point to note is that all these design challenges apply generally to market-based systems, such as taxes or cap-and-trade systems. An important difference, however, is the establishment of a reference case. In a pure cap-and-trade system, for example, an emitter will be required to have a number of allowances that corresponds to his actual emissions. That is, his baseline will frequently be zero. In contrast, the baseline under most offset instruments is less clear. Policy makers must determine whether the emission reductions are truly "additional." To do this, they must identify a baseline or counterfactual from which to judge additionality, which is frequently very hard to may be subject to gaming on the part of the participants.

The basic design challenge for offset systems is to balance the goals of protecting the environment (i.e., assuring the offset program does not compromise the core regulation), 
increasing the use of low cost offset opportunities, and reducing the transactions costs of implementing the offset program. There are many aspects of an offset system that may introduce uncertainties in the actual level of environmental quality that will be achieved. For example, the environmental property rights for even the core group of regulated entities may not always be well-defined under the current regulatory system because there may be a difference between a firm's actual activities and what it is permitted to do.

When the offsetting activities come from entirely outside the core regulation, the baseline level of emissions can be even more difficult to assess because the regulator must guess at the appropriate reference case (Montero 2000; Bushnell 2010). Regulators may want to take into account the fact that the firms most likely to participate in the system are those that get a generous level of property rights relative to their actual baseline level of pollution. This is sometimes referred to as the problem of adverse selection. The baseline problem is further compounded by the fact that some firms involved in generating offsets may be able to affect their baseline allocation by strategically manipulating the regulatory decision maker (sometimes referred to as the problem of moral hazard).

To illustrate how the design of offsets can give rise to perverse results when baseline determination is not accurate, see Figure 1. In this figure we consider a horizontal marginal benefit curve associated with a price of $\$ 2$. By assumption there are two different offset activities that define the marginal cost curve - one that can be undertaken by firm 1 at a cost of $\$ 1$ and a second that can be undertaken by firm 2 at a cost of $\$ 3$. Each results in 1 unit of abatement as shown in the figure. If the regulator knew the precise amount of credits to give for each activity, it would give 1 unit for each activity, and firm 1 would abate because its cost is below the price and firm 2 would not abate because its cost is above the price. This would be the efficient solution because firms only engage in clean up if their marginal costs do not exceed the marginal benefits.

Now, suppose for the sake of argument that the regulator would give firm 1 one-third of a credit for its abatement activity, but would give firm 2 two credits for its activity. In this case, firm 1 will not engage in clean up because it would only get $\$ 0.67(\$ 2 * 1 / 3)$ for cleaning up and it costs $\$ 1$ to clean up. In contrast, firm 2 will engage in cleanup because it receives $\$ 4(\$ 2 * 2)$ for cleaning up and its cleanup cost is $\$ 3$. This solution is inefficient because the high-cost firm, whose marginal cost of abatement exceeds marginal benefits, engages in cleanup; while the low cost firm does not, even though the marginal benefits exceeds its marginal cost. So, in theory, if the regulator sets the baseline incorrectly, society could end up with a highly inefficient result. Furthermore, in this example, environmental quality would likely be compromised as well. Firm 2 would receive 2 credits for only reducing pollution by 1 unit, which means net environmental quality could decline by one unit.

We constructed this example to illustrate one important potential problem with offsets. Project developers know more about their own circumstances than regulators. It is likely that the parties best able to advantageously obscure their reference cases will be most attracted to apply for credit. In general, the larger the number of projects, and the more heterogeneous the projects, the more important will be the role of information asymmetries. To overcome the asymmetries of information regulators can require a great deal of reference case documentation from offsetters, and administrators can invest in information gathering, investigation and evaluation. This raises the social cost of offsets and may diminish the advantages of an offsets system. In general there will be a tradeoff between raising overall compliance costs and assuring better environmental protection. 
In general, there are no simple solutions to the offset design problem. There are three different kinds of solutions that have been proposed. One is to give out enough property rights to all possible offsetting parties so that there will be no issues with adverse selection or moral hazard (e.g., Montero, 2000). The problem with this approach is that it may not be feasible politically because it could involve significant wealth transfers. A second approach is to try to get better information on the nature of the baseline or counterfactual. This approach has serious limitations; it is frequently hard to identify what a firm or industry's emissions might have been in the absence of the offset policy. Bushnell (2010) suggests a randomized trial to ascertain the likely impact of an offset policy. Even if this were doable, and we have our doubts, we are not sure how much light it would shed on establishing a relevant baseline for particular entities that are eligible to participate in such a program. A third approach is to impose restrictions on the offset program itself. Examples include putting a cap on offsets, taxing offsets relative to other types of transactions, and limiting who can trade offsets. These measures may limit the number of offset trades, but will not likely do much to address problems associated with adverse selection or moral hazard. Precisely because there are fundamental problems with design, we see offsets as a second-best approach that should be employed when other more efficient approaches are not likely to be politically or legally feasible.

At their core, offsets represent one way of compensating for social damages that result from projects. If this compensation does not provide sufficient motivation to balance marginal social benefits with marginal social costs, then alternatives should be considered. An alternative approach would be to calculate the damages from projects on a case-by-case basis and require appropriate compensation for those damages. The problem with this approach, however, is that it can give rise to very high transaction costs in determining appropriate levels of compensation. Offsets, and other more traditional regulatory mechanisms, such as standards, cap-and-trade, and taxes, can help to reduce these transaction costs in theory; whether these cost reductions are likely worth it depends on how the policy instrument is designed in practice.

\section{Offset Programs in Practice}

While offset programs are simple in concept, experience suggests that administration of offset programs has been challenging in practice. To explore the potential of the offset approach and the factors that limit their effectiveness, we consider the experience with several different types of programs. First we provide an overview of several offset programs, examine how those programs are structured, and assess the impacts they have had on environmental outcomes and cost. Then we examine three programs in detail: the Clean Development Mechanism for greenhouse gas emissions, point-nonpoint source water pollution trading programs, and wetlands mitigation banking.

\section{The Breadth of Offset Programs}

While carbon offsets may be the most visible application in the media and academic literature, the concept of offsets substantially predates the focus on climate change. Offsets provisions were not only incorporated into the Clean Air Act in 1977, but have been integrated into a wide range of environmental regulations and programs, covering water quality, habitat protection, and energy as well as greenhouse gases and air quality. Geographically the offsets approach has been employed in many different countries, including the United States, Canada, the United 
Kingdom, France, Italy, Brazil, Australia and New Zealand, and at local, state/provincial, national, regional and global scales.

Table 1 provides an overview of a number of offset programs that illustrate the basic nature of this approach as well as the breadth of its application. No attempt was made to provide an exhaustive list of offset programs or even offset applications (for a more extensive review of carbon offset programs, see Kollmus et al. 2008); rather, this sample was chosen to provide insight into the many design issues and challenges that accompany offset programs.

The table illustrates several important issues. First, offsets are used in a wide range of applications, including greenhouse gas emissions, air and water quality, energy, and habitat and biodiversity. Second, consistent with the definition of offsets, all programs in Table 1, with one exception, include a combination of a core regulation and an offset program intended to lower the costs of the core program without compromising the environmental goal. The exception is the Montgomery County tradable development right program, which we include to illustrate the boundaries of the offset concept.

Third, offset programs arise under a number of different types of legal mechanisms. CDM and JI arise under the Kyoto Protocol to the UN Framework Convention on Climate Change; others, such as the UK White Certificates plan, are implemented at the national level, while others, such as the vegetative offsets program in Victoria, Australia and the greenhouse gas Offsets Credit System in Alberta, Canada are implemented at the state or provincial level. In some cases (e.g., wetlands mitigation banking and point-nonpoint source water pollution trading in the United States) the core regulation is national law, but the offset provisions arise under cooperative agreements to implement the law.

\section{Comparing Design Features Across Programs}

Table 2 provides a summary of some key design features of offset programs. A fundamental decision in designing an offset program is the choice of equivalency approach, i.e., the means by which the program attempts to ensure that the environmental benefits of the offset measure are equivalent to or exceed the environmental damage due to relaxation of obligations under the core regulation. There are at least three approaches to equivalency. Deemed equivalency is a categorical, input-based approach that lists the amount of reward associated with specific offset actions. For example, the Italian White Certificates program provides a table of presumed energy savings associated with activities such as substituting a compact fluorescent bulb for an incandescent bulb. The advantage of this approach is that it reduces uncertainty and transactions costs. A disadvantage is that it does not try to measure actual impacts.

Financial equivalency is a variation of deemed equivalency. Financial equivalency is based on the amount of resources spent on offsets, rather than the actual environmental impact of the offset activity. Thus, this approach does not guarantee environmental equivalence. Under one version of financial equivalency, regulated firms have the option of simply buying out of the offset requirement at a specific price. In a further variation, as in the Tar Pamlico water quality trading approach, the state is the sole supplier of offsets, using money collected to implement regulator-designed offset projects. In this form, the offset system actually reduces to an emissions fee with revenues earmarked for projects.

The demonstrated equivalency approach requires offset project developers to provide analysis demonstrating that the project, in fact, provides environmental benefits equivalent to the amount of the offset award. The emphasis is on the methods used to conduct the analysis. In some 
cases, such as the CDM, the burden is on the offset developer to provide a method to ensure certified projects produce "real, measurable and verifiable emission reductions that are additional to what would have occurred without the project." 3 Similarly, under the offsets provisions of the U.S. Clean Air Act, firms had to demonstrate that existing firms' who offered offsets were emitting below their permitted level. Demonstrated equivalency can be a demanding standard, designed to protect against environmental degradation.

Under negotiated equivalency, the administering agency assesses individual proposals and works with applicants to determine the projects or actions that will be approved as offsets. The administrators typically have a great deal of discretion, combining standards and modeling tools with professional judgment. This approach is used in controlling New South Wales salt emissions where there were extensive discussions between the regulators and the offsetters. Similarly, under the Natura 2000 system, when development is going to have a significant impact on a protected area, national representatives work with developers to identify adequate measures to offset the impacts.

The approach to defining equivalency is closely related to the choice of a unit of measure for the environmental tradeoff. In some cases this choice may be straightforward, such as a metric ton of net carbon emissions; but even here, there may be other effects, such as those related to local air pollution that may be important. In other applications the choice of units is not as clear. For example, in the case of wetlands mitigation banking, the wide variety of wetlands types and qualities each present a difference set of environmental amenities. Put simply, not all wetlands are created equal. When a wetland area is destroyed an array of environmental services - e.g., flood control, nutrient filtering, and wildlife habitat - can be lost.

As noted above, a key issue in offset estimation is identification of a counterfactual or reference case. The determination of the reference case is extremely important for offset projects, sometimes affecting whether a project will be profitable. Some programs, such as the CDM, require a projected reference case for emissions - a business-as-usual description.

In programs involving either ex post rewards or adjustment of ex ante rewards based on ex post observation, some form of monitoring, measurement and verification is required. This might entail inspection to confirm that the required steps have been taken, as in the case of the Italian White Certificates program; or it might involve metering, as in the case of the Texas Renewable Energy Certificate Program or the UK Renewable Obligation Certificate program. In some cases, there may be a more involved assessment to assure not only the extent of the offset activity, but the quality. This is the case with various habitat and biodiversity programs.

Just as with other regulatory programs, the indirect impacts of offset programs need to be considered. For example, at the individual level, when energy efficiency increases by 10 percent, the effective cost of energy services declines. This can lead to more energy used, so that actual energy use is not reduced by 10 percent. Similarly, at the aggregate level, if one region or country reduces its demand for energy use, the price of energy will drop. This will result in an increase in energy use outside the region or country.

The degree of "leakage" - or movement of environmental damages elsewhere - will depend on the features of the offset program and the particular activity. For example, we believe that leakage is likely to be less of a problem for wetlands than it is for carbon offsets. Suppose that wetlands demand is related to the housing demand in a particular place. If the demand for housing in the United States were not easily substituted for housing elsewhere, then developers

\footnotetext{
${ }^{3}$ See, http://cdm.unfccc.int/about/index.html, accessed September 27, 2010.
} 
will not likely go abroad to meet the U.S. demand. They will then be subject to similar no-netloss of wetlands policies across the U.S., thus reducing chances for leakage. In contrast, in the field of carbon offsets, leakage can be a substantial problem, as producers may choose to relocate to low-cost regions. A complete treatment of leakage is beyond the scope of this paper, but two points are worth noting. First, leakage may be significant for some applications, but is hard to estimate. Second, in most partial regulatory systems, there is likely to be leakage. Issues related to the equivalence of offsets should be judged in that light.

Several offset programs introduce a trading ratio to address concerns raised by environmental interest groups. Frequently, that ratio is based on non-economic criteria and can give rise to inefficiencies. The ratio typically determines the number of units of offsets required for each unit of reward under the core regulation. For example, the trading ratios required for the wetlands program is typically higher than one to one, meaning that the permittee must create more than one acre of mitigation wetlands for each acre that is destroyed. The New South Wales water quality program required 1.5 tons of reduction in salt loading for each additional ton the party was allowed at the point source.

The form of reward under offset programs varies depending on the nature of the core regulatory program, and the role of offsets. A wetland banking program, for example, rewards participants with relaxation of the restrictions on destruction of wetlands. A carbon offset program could reward projects by issuing additional allowances.

\section{Three Case Studies of Offsets}

\section{The Clean Development Mechanism}

The goal of the Kyoto Protocol's first commitment period is to reduce the aggregate developed nations' greenhouse gas emissions by 5.2 percent below 1990 levels between 2008 and 2012, the first commitment period. These emissions include the six greenhouse gases: carbon dioxide, methane, nitrous oxide, hydrofluorocarbons (HFCs), perfluorocarbons, and sulphur hexafluoride. Since the global warming potential of each pollutant can be estimated, reductions can be expressed in $\mathrm{CO}_{2}$ equivalents (Solomon et al. 2007).

To reduce the costs of achieving this goal, Kyoto includes mechanisms such as emissions trading among participating countries (e.g., Hahn and Stavins, 1999). The Kyoto Protocol also includes the Clean Development Mechanism (CDM), which allows Annex I nations (developed nations with individual emission budgets) to implement emissions reduction projects in nonAnnex I nations that are not subject to any caps. These projects generate certified emission reductions (equivalent to one metric ton of $\mathrm{CO}_{2}$ ) that can be used by Annex I nations to help achieve their emission reduction requirements.

The Kyoto Protocol defines two goals for the CDM: cost savings in meeting carbon emission budgets of Annex I nations and the promotion of sustainable development (UNFCCC 1998). The CDM can meet the first goal by letting Annex I nations implement projects in developing nations, where emission reductions often can be accomplished at a much lower cost than in developed nations (Hepburn 2007). Because this involves investment flows into developing nations from industrialized nations it can also promote growth in developing nations without increasing greenhouse gas emissions.

CDM projects have been significant by some measures. According to the UNFCCC (2010a), there are currently 2,483 CDM projects registered. As of November 2010 certified emission 
reductions equivalent to a total of 451 million metric tons of $\mathrm{CO}_{2}$ emissions had been issued since the start of the CDM. The World Bank estimates that from 2008-2012 the CDM will provide offsets equivalent to 1 billion metric tons $\mathrm{CO}_{2}$ equivalent (Kossoy and Ambrosi 2010). One main driver in the expansion of the CDM has been the European Union Emissions Trading Scheme (EU ETS) that has allowed for certified emission reductions from the CDM to offset domestic emissions (Ellerman and Buchner 2007, Hepburn 2007). Of the 211 million ton of certificates contracted within the CDM in $2009,84 \%$ were sold directly to the private sector or to the government of a country complying with the EU ETS (Kossoy and Ambrosi 2010). In the 2008-2012 period the EU ETS is forecasted to demand certificates equivalent to 540 million metric tons of $\mathrm{CO}_{2}$ from the CDM (Kossoy and Ambrosi 2010). ${ }^{4}$

To date, most certified emission reductions have been issued for projects in a small number of countries (Hepburn 2007; UNEP 2010). China is the largest generator of CERs, accounting for $51 \%$, followed by India with 18\%, then South Korea with 13\%, and Brazil with 10\% (UNFCCC 2010a).

Figure 2 shows that certified emission reductionss have been issued for a wide range of projects between 2005 and 2010. The majority of issued certified emission reductions to date have been issued for the capture and destruction of HFCs and nitrous oxide gases, which are biproducts of industrial processes. Projects reducing the emissions of HFCs have accounted for $49 \%$ of total issuance while $\mathrm{N}_{2} \mathrm{O}$ projects have accounted for $25 \%$. $^{5}$ The most rapidly growing sector for offsets projects is renewable energy, which is mainly energy from biomass, wind and hydro power plants (UNEP 2010). Of total certificates issued, $14 \%$ have been for renewable energy projects (UNEP 2010). Other sectors that are projected to grow in the future are energy efficiency improvement projects, projects reducing methane emissions from coal mines and landfills, and projects that use less carbon-intensive fuels (UNEP 2010).

When assessing the CDM it is important to note that the objective of the CDM is not to reduce greenhouse gas emissions per se, but to reduce the cost of greenhouse gas emission control and promote sustainable development of non-annex I countries. It may also be a key factor that gets countries to participate in an agreement.

CDM has faced some major problems, and its effectiveness has been debated in the literature (e.g., Victor 2010, Grubb et al. 2009). A key concern is whether emissions reductions have been additional, in the sense of truly reducing greenhouse gas emissions on a local or global basis. Under recent rules, project developers can employ one of over 130 approved methodologies for determining baselines and monitoring the project, or they can submit a new approach to an oversight UN board for approval (UNEP 2010; UNFCCC 2010b). Development of such methodologies is costly and time-consuming (Michaelowa et al. 2009). Furthermore, there are strong incentives for host countries and buyers of the certificates to overstate the baseline emissions.

There is evidence that some projects that are not additional have been approved by the executive Board. For example, in China all renewable energy projects were deemed eligible to receive CDM credits, even though China's energy policy already calls for some renewable energy development to meet growing demand (Wara and Victor 2008). Indeed, the CDM's

\footnotetext{
${ }^{4} \mathrm{~A}$ minority of these certified emission reductions are forecasted to be supplied by the Joint Implementation mechanism.

${ }^{5}$ Author's own calculation based on UNEP 2010 data.
} 
administrative body launched reviews into whether several Chinese wind projects deserve credit (He and Morse 2010), and those reviews are widely seen as an early step in tightening up the program's administration.

Despite a significant amount of research into the area of additionality, there is a paucity of good data on this subject. For example, Schneider (2009) assessed 93 CDM projects that were sampled from the 768 projects registered as of July 2007 to evaluate the methodologies used to demonstrate additionality. His analysis concludes that "...that the current tools for demonstrating additionality are in need of substantial improvement. In particular, the application of the barrier analysis is highly subjective and difficult to validate in an objective and transparent manner. Key assumptions regarding additionality are often not substantiated with credible, documented evidence. In a considerable number of cases it is questionable whether the emission reductions are actually additional." (Schneider, 2009, p. 242). Similarly, Michaelowa and Purohit (2007) evaluate 52 CDM projects in India, finding that only about half of the projects even considered alternative projects in their additionality assessment. The authors assess 19 of the projects in more detail, and find that fewer than half of the large projects provide sufficient information about additionality in their documentation.

The main objective of the CDM is to reduce the cost of emission abatement for Annex I nations, but some evidence suggests that CDM may actually confound cost-effective pollution reduction in some cases. For example, abating all HFC-23 emissions in the developing world is estimated to cost approximately $\$ 31$ million per year. Because of the subsidy implicit in CDM credits, however, industrialized nations spent significantly more ( $€ 270-€ 750$ million, or roughly $\$ 400-\$ 1200$ million) to achieve these reductions in 2005 (Wara 2008). According to Hepburn (2007), the prices paid for certified emission reductions are approximately ten times the actual marginal cost of HFC-23 removal. In fact, the removal of HFC-23 for the generation of certified emission reductions is more lucrative than production of the refrigerant from which the HFC-23 is a byproduct (Wara and Victor 2008). In an effort to address this problem, rules were later changed to restrict HFC-23 projects. ${ }^{6}$

Several studies have considered the transactions costs associated with the CDM mechanism (Michaelowa and Jotzo 2003; Krey 2005; Chadwick 2006). Examples of transactions costs include the costs of applying for credit, monitoring projects and reporting results. Transaction costs are often cited as a serious challenge to the successful deployment of CDM (Michaelowa and Jotzo 2003; Krey 2005; Chadwick 2006). CDM likely has significantly higher transaction costs than a pure cap-and-trade regime among regulated sources because each project has to be approved. Notwithstanding the concerns about transactions, there is still a significant level of activity. For example, in 2009 the total value of certificates contracted within the CDM were \$2.7 billion (Kossoy and Ambrosi 2010).

Some scholars have noted that the CDM market is working reasonably well because of the level of activity that is observed. We would agree that the CDM market is functioning, but the real question is whether its benefits justify its costs. We do not really know the proportion of projects that actually add result in incremental emission reductions, for example.

The impact on "sustainable development" is virtually impossible to measure because the term is not well-defined, but scholars have tried (e.g., Olsen 2007). As noted above, the impact on

\footnotetext{
${ }^{6}$ See Methodology AM0001: Incineration of HFC 23 Waste Streams. Version 5.0.2

https://cdm.unfccc.int/methodologies/DB/OMKGF12PM6TSNFNJZUESTSKG581HN6/view.html
} 
emissions reductions is unclear, so it is hard to claim much benefit there. It might be asked, then, whether the transfers associated with CDM encourage the development of new technologies, such as renewables. While such transfers undoubtedly have a positive impact, there is little reason to believe on the basis of past experience that the benefits of such transfers justify the costs (e.g., Cohen and Noll 1991). At the same time, it would be nice to have a rigorous analysis of these issues in the context of CDM.

\section{Nonpoint Source Water Pollution}

Most water pollution regulations under the U.S. Clean Water Act focus on point sources of pollution, which are required to obtain permits under the National Pollution Discharge Elimination System (NPDES). However, in many cases, it is much less costly for unregulated nonpoint sources (such as agricultural runoff) to reduce pollution discharges than for point sources to install control technologies. Allowing point sources to offset their own emissions by providing or paying for nonpoint reductions may achieve the same water quality goals but at lower social cost.

The Clean Water Act does not specifically authorize water quality trading, and does not even directly address nonpoint sources of water pollution. This creates a regulatory environment where offset programs face legal constraints and barriers (Woodward et al. 2002). However, there are at least two regulatory mechanisms under which trading programs may be implemented - one that imposes constraints on groups of emitters and one that affects individual firms. When the U.S. EPA establishes an emissions limit for an entire watershed or water body - a total maximum daily load - several emitters have to simultaneously make reductions. In this case markets can emerge with nonpoint sources generating offset credits for sale via bilateral negotiations or clearinghouses. In contrast, offsets set up under permit agreements with individual firms are usually one-time deals, involve only one point source and one or more nonpoint sources, and require the direct involvement of the regulatory agency through every step of the negotiation process.

The programs that best fit with the definition of offset programs tend to use clearinghouse structures, which convert nonpoint source reductions to credits that point sources can purchase (Breetz et al. 2004). For several of these programs, however, no trading has occurred because restrictions on point sources are not binding (Cherry Creek), nonpoint source reductions are considered more costly than point source reductions (Long Island Sound), or the point source driving the program goes out of business before the program is complete.

Measurement creates a particular challenge for the inclusion of nonpoint sources in offset markets. Nonpoint source pollution generally cannot be directly traded because it can not be routinely or accurately metered at any reasonable cost (Horan 2002). Compared to air pollution emissions, which are relatively fungible, water pollution exchanges between sources (especially involving nonpoint sources) are less comparable and more expensive to measure (King and Kuch 2003). In most of the offset programs and one-time offset agreements, credits are generated based on an ex ante basis, with certain activities that are expected to result in pollution reduction—not for actual, measured reductions (Fang, et al. 2005).

Water quality trading programs are necessarily implemented at the watershed level, which introduces further complications when compared with air quality trading programs. For example, watersheds are generally much smaller than airsheds, which make for much thinner markets (Woodward, et al. 2002; Keiser and Fang 2005). Also, although nonpoint sources are not 
federally regulated under the CWA, many states and localities have best management practices regulations (EPA 2008a). These alternative regulations can complicate identification of the reference case or baseline. For example, programs that expand "green payments" to farmers for practicing good land management change the baseline for nonpoint source runoff.

It is difficult to establish equivalency between point discharges and nonpoint nutrient discharge reductions and in calculating the reductions from these projects (King and Kuch 2003; Morgan and Wolverton 2005; EPA 2008a). Impacts from nonpoint sources are often difficult to estimate, making the development of a trading ratio difficult (Woodward et al. 2002). Trouble with equivalency also comes from unpredictable weather, verifiability of nonpoint source load models, and the lack of certainty regarding long-term impacts in the receiving waters (Fang et al. 2005). This lends support for case-by-case, regulator-approved trades rather than a "commoditystyle" market system. The case-by-case approach results can result in significant transaction costs (King and Kuch 2003).

In much of the literature, it appears that the mark of a successful program is that actual trades occur. However, in most cases, the stated program objective is for environmental quality goals to be achieved at the lowest economic cost (Breetz et al. 2004; Keiser and Fang 2005). In some cases, programs were declared successful even in the absence of trading because this larger goal was recognized. In other cases, the program was deemed a success because it facilitated industrial growth in an area (usually a one-time agreement) without sacrificing environmental quality (Breetz et al. 2004; Keiser and Fang 2005). None of the cases cited in the literature resulted in decreased water quality which means that there is no evidence that any program so far has sacrificed environmental targets in pursuit of trading.

Although most projects are still in the developmental stage, some evidence suggests that point/nonpoint trading can result in significant cost savings. For example, a preliminary economic analysis of a program in the Miami Conservancy District in Ohio estimates that nonpoint source reductions that could meet point source demand for credits could be achieved at approximately 8-26 percent of the costs of using point source controls exclusively (Keiser \& Associates 2004), and that total savings from the offset program could total \$314- \$385 million (EPA 2008a).

Breetz et al. (2004) also cite some examples of reported cost savings. For example, Boulder Creek sources saved between $\$ 3$ and $\$ 7$ million by using best management practices to reduce nonpoint sources of pollution. Another one-time agreement which allowed a firm to avoid constructing a pollution control lagoon via nonpoint source offsets saved approximately $\$ 3.25$ million.

Despite a high degree of interest in water quality trading, especially between point and nonpoint sources, most projects to date have not experienced a high trading volume, and many pilot programs have not been scaled up to full deployment (EPA 2008a). Fang et al. (2005) suggest that the two main reasons for the low level of trading are high transaction costs and opposition from environmental groups.

There is a great deal of support in the literature for transaction costs being a major hurdle to the successful deployment of water quality offset programs (Breetz et al. 2004; Fang et al. 2005; Morgan and Wolverton 2005). These include permit negotiation, trade partner searches, administrative expenditures (such as payroll), communications between regulated sources and regulatory agencies, credit verification, post-project site inspection, and routine project management (Fang et al. 2005). The transaction and administrative costs seem particularly large in the one-time agreements since the point source has to first arrange a deal with the agency and 
then with landowners where the project will occur. According to Fang et al. (2005), who evaluated two major one-time offset deals in Minnesota, the permitting phase was very costly to both the regulatory agency and the point source. There was an estimated $\$ 105,032$ in transaction costs for one deal, 65 percent of which occurred before any trades took place, and 81 percent of which was borne by the regulatory agency, not the point source.

To account for uncertainty, trading ratios are sometimes used. For example, two or more units of nonpoint pollution reductions may be required to allow for a one-unit increase in point source discharges. However, this can reduce the cost savings associated with nonpoint source offsets and also puts an effective tax on exchanges. As a result, cost differentials have to be substantial to induce point sources to engage in trading, especially given the transaction costs involved with finding and negotiating with trading partners (Breetz et al. 2004).

The picture that emerges from point-nonpoint source trading is one of little trading because transaction costs are high. A substantial number of trades appear to be one-time offset agreements between individual companies and state regulators. For the trades that have occurred, it appears that environmental quality has been preserved. Furthermore, simulations suggest there is a potential for cost savings. This picture is not that different from an earlier analysis by one of the authors of this article two decades ago (Hahn 1989).

\section{Wetlands}

Wetlands provide many ecologically and economically valuable services, including, water storage, sediment trapping, and wildlife habitat (Hoeltje and Cole 2007). Section 404 of the Clean Water Act governs the nation's wetlands. It is jointly implemented by the Army Corps of Engineers and the EPA. Anyone wishing to dredge or fill a wetland for development (or any other purpose) is required to obtain a permit from the Corps.

In 1989, the Bush administration set a "no net loss" goal for the nation's wetlands. To achieve this goal, the Corps can require that permitted sources undertake mitigation to replace wetlands that are lost or damaged. This can entail the construction of new wetlands, restoration of previous wetlands, or in some cases the permanent preservation of existing wetlands. The administration of the program by the Corp is decentralized, and there is a great deal of variation of how different districts manage permit requests.

Wetland mitigation is widespread. Every year, about 47,000 acres of new wetlands are required to compensate for 21,000 acres of permitted losses (Kihslinger 2008). At the outset, wetland mitigation was done exclusively on an individual project level, with the party receiving the permit fully responsible for implementation. Today, that party still typically is fully responsible.

Mitigation banks began to arise in the late 1980s and early 1990s (Robertson 2006). They were initiated by state transportation agencies to fill their own needs, but entrepreneurs soon began to develop them as well. Instead of constructing mitigation wetlands individually, permit holders can instead purchase credits from a bank.

Mitigation banking has grown rapidly in the last 20 years. There were 219 active banks with 50,000 hectares in 29 states by 2002 (Spieles 2005), and today there are more than 300, with 78 percent of them being for-profit ventures (Robertson 2006; Hough and Robertson 2009). Of the active banks, 75 of them are sold out of credits (Hough and Robertson 2009). Overall, mitigation banks account for about a third of all mitigation wetland acres in the United States. In the Chicago area (which frequently serves as a model for other regions), regulators award the mitigation credits gradually (Robertson 2006). The phased release of credits, some of which 
occurs before project completion, is necessitated by the substantial upfront capital costs associated with the projects.

Mitigation banks theoretically have many advantages over individual projects. The credits are generated prior to the destruction of natural wetlands; they encompass larger areas and can accommodate many permits, and they can be placed in more ideal locations ecologically and hydrologically (Spieles 2005).

Performance standards are a critical element of wetland mitigation banks. Although there are no national standards in place to guide performance goals, the vast majority of cases employ performance standards focused on vegetation (Spieles 2005; Matthews and Endress 2008). These standards are often established somewhat arbitrarily without reference to a particular natural wetland and without measurable targets (Matthews and Endress 2008). Although some performance standards are objective and measurable, others include highly subjective measures of success, such as "good survival" of planted trees.

Enforcement is frequently a problem in wetland mitigation. Monitoring, submission of reports, and long-term maintenance are frequently performed poorly (Kihslinger 2008). Further, the Corps does not generally write penalties into permits, so they have no legal recourse in the case of noncompliance (GAO 2005).

Most studies of ecological equivalency between natural and compensatory wetlands have discouraging results, with only about 17-21 percent of mitigation sites adequately replacing the functions of lost wetlands (Kihslinger 2008). Matthews and Endress (2008) found that only 23 out of 76 evaluated sites achieved all of their stated goals, and 8 failed to achieve any goals. Further, the sites that achieved a higher proportion of goals virtually always had fewer goals and lower thresholds for success.

System-wide impacts are also a major concern (Hoeltje and Cole 2007; Kettlewell et al. 2008). Often, evaluations of individual projects do not consider watershed-wide impacts that accrue when multiple wetlands are replaced via mitigation projects. This is especially important given that many wetlands functions are heavily dependent on their surroundings. Many mitigation wetlands are located far away from or even outside the watershed of the natural wetland they are intended to replace.

The picture that emerges from wetlands mitigation is mixed. There is more trading than in some other programs, such as point-nonpoint source offsets. The net environmental impact is not always positive, though; markets exist, but are thin; and establishing equivalency across different kinds of wetlands is difficult.

\section{Why are there Offset Programs?}

Based on theory and practice, we believe that offset policies are often an imperfect economic instrument that can serve useful political ends. To see why offsets are likely to be inefficient, consider the following thought experiment. Suppose property rights were well-defined, easily enforced, and governments could agree on an environmental target. Then, it would typically be more efficient to have a cap-and-trade system than a cap-and-trade system combined with an offset system.

Yet, notwithstanding the fact that offset policies may be inefficient, we observe these policies in many applications. We believe there are several reasons for the use of offsets, the primary ones being political and legal. It is also possible that government agencies adopt offset programs 
when it is particularly difficult to incorporate some environmental protection activities in the core regulation.

Suppose that voters can only imperfectly monitor the actions of politicians and legislators. Then, an offset regime can sometimes offer decision makers an opportunity to deceive voters. For example, politicians may promise a certain amount of environmental quality (say greenhouse gas reductions in the United States). They may then introduce an offset provision that gives the appearance that it will allow equivalent reductions, but because of possible gaming on the part of participants, will not deliver as promised. In a sense, this is a win for politicians because they can gain politically while shifting the general costs (in terms of less environmental quality than promised) to the poorly informed public. Specific interests within the business community who engage in these projects would also stand to gain from an offset system, and politicians may be able to extract some of these gains (Liu, 2010). Indeed, it may be possible for polluters to more easily manipulate offsets to their advantage than other more traditional mechanisms for pollution control, which could explain some of the opposition from the environmental community.

A related explanation for offsets is that there may not be agreement about the underlying distribution of property rights. For example, a developed country might be willing to agree to a firm goal on a greenhouse gas emissions target, but a developing country might not. In this case, the developing country might find it advantageous to allow an offset program (say in the form of $\mathrm{CDM}$ ) to proceed without agreeing to a firm target. Indeed an offset program may allow that country and project developers in that country to claim they are helping to solve the problem. At the same time, the developing country is not committing itself to a firm target, but is giving itself the option of extracting rents (in the form of financial transfers from the developed country) in the future. If key countries have market power in the supply of offsets, as Victor (2010) has argued in the case of CDM, they will be able to extract more rents.

Some proponents of offsets have argued that encouraging countries like China to participate in an offset system may make it more likely that these countries join a cap-and-trade regulatory regime later on. While it is possible that such regimes may increase a country's monitoring and enforcement capabilities, they also make it less attractive for that country to join a cap-and-trade regime because of the benefits that now accrue to the country under the offset regime (Hepburn, 2007).

Some commentators have argued that the Clean Development Mechanism may make it more likely that developing nations will eventually agree to nationwide targets on carbon dioxide or greenhouse gas emissions. For example, Ellis et al. (2007) argue that a long-term international commitment to a mechanism like CDM may actually encourage more countries to make commitments early on, so that they can take advantage of low-cost reductions at the outset instead of leaving the lowest cost reductions available for CDM investors. But if most of the low-cost reductions are used up, it may make it harder to economically and politically justify stringent developing country targets later. A related argument is that offsets may allow developing nations to develop institutional capabilities, which could increase their demand for reducing climate change emissions (Ellis 2007). While offsets may affect the demand for environmental quality in a country, the size of the effect is likely to be small, except for those particular constituencies that benefit.

Rather than encouraging countries to make binding commitments, we believe that the CDM as implemented currently is likely to have the opposite effect. A country will typically weigh the costs and benefits of entering into a climate agreement with binding targets. Consider three 
possibilities for a developing country: 1) it has no binding target; 2) it has no binding target and uses CDM; or 3) it has a binding target. From the perspective of the developing country, purely on narrow economic grounds, situation 2 is likely to be preferable to 1 because CDM increases revenues coming into the country without imposing any significant costs. At the same time, $\mathrm{CDM}$ actually raises the opportunity cost for that country of entering into a binding agreement at a given level - that is option 3 becomes relatively less attractive to the developing country. The reason is that CDM serves as an effective subsidy to the developing country. In this sense, CDM may create perverse incentives, since governments in developing countries have incentives not to impose emission restrictions if it means that they can set a relaxed baseline and attract lucrative CDM investments (Dutschke 2000; Hepburn 2007; Wara and Victor 2008). Figueres (2006) discusses several Latin American examples of this phenomenon, wherein governments have hesitated to implement environmental policies for fear of invalidating potentially lucrative CDM projects underway in their nations.

While offsets may make it less likely that a country not participating in an agreement will join an agreement later on, they may increase the likelihood that some countries will participate in an agreement at the outset. This is because offsets can lower the cost of achieving the stated target for those countries that agree to a binding target.

Another possible explanation for the use of offsets is that they help address potential legal constraints. Consider the case of climate change regulation. There are two basic strategies to reduce net carbon emissions-reduce emissions and increase forest carbon sequestration. One approach to reducing net emissions would be to include both activities under a core regulation that not only required sources to reduce emissions, but mandated the establishment of tree plantations on certain private land holdings. However, the latter law would not likely be constitutional in the United States; in general, the government can prevent harms (regulate emissions) but not require private production of benefits (capturing carbon dioxide). Similarly, the government can prevent the destruction of wetlands, but it cannot force landowners to create new wetlands without compensation. Thus, even though activities such as carbon sequestration and wetlands creation are effective ways to provide environmental quality, they must be induced through the offset system rather than required by regulation.

There also may be significant transaction costs associated with defining a reasonable cap-andtrade regime. In such cases, offsets may represent a useful political compromise. Again, the China-U.S. greenhouse gas example above can be illustrative. Suppose that China might be willing to reach an agreement on targets with the U.S. but the bargaining costs are high. An offset program may be viewed as a sub-optimal instrument if we assume away such bargaining costs, but may be quite attractive in the presence of such transaction costs.

Finally, offsets may be seen as an evolutionary step in moving away from command-andcontrol regulation that may be attractive precisely because it is incremental in scope (Haddad and Palmisano, 2001). In that sense, they may serve as a bridge between command-and-control systems and cap-and-trade systems. They can provide some flexibility in reaching a regulatory goal, while at the same time, imposing restrictions that certain interest groups and elected officials view as desirable.

A critical question for policy makers and analysts interested in promoting economic efficiency is how to move from an offset regime that is more efficient and effective. The answer will differ in specific applications, but the broad outlines of a solution must rely on a careful analysis of the political winners and losers associated with various reforms. Victor (2010), for example, argues that the U.S. could create an offset system under CDM that both encourages greater competition 
among suppliers and imposes higher quality thresholds for certifying offsets. It remains to be seen whether the U.S. would want to impose such thresholds, but the idea is clever in that it relies on a third party - in this case, the U.S. - to help transform the status quo.

\section{Conclusions and Areas for Further Research}

This paper provides a survey and synthesis of the literature on the use offsets. We began by developing a definition for offsets because the term has been used loosely in the literature. Our definition focuses on offsets as a mechanism for reducing the cost of core regulatory activities while still trying to maintain the same, or a comparable, level of environmental quality. We then analyzed theoretical justifications for offsets as well as how they are used in practice.

The theory of offsets is fairly well understood. With perfect information, theory requires equating marginal abatement costs across sources. When one allows for the fact that offsets could involve gaming on the part of the regulated entity or a country, the theory is more complicated, and suggests that offsets could easily give rise to inefficiencies and reduce environmental quality. The incentives to overstate emission reductions need to be taken into account in assessing the likely effectiveness of offsets.

Our review underscores several key points. For example, the design and success of offsets will depend significantly on the scientific, economic, political and legal environment in which they are implemented. In some cases, such as point-nonpoint source offsets, there has been little activity. In other cases, such as wetlands banking there has been a lot more activity. In general, it is not clear that offset programs have had a sizable impact on environmental quality, but they do appear to lower costs somewhat. In the case of wetlands, they appear to have resulted in declines in environmental quality in some cases.

In different contexts, offsets will encounter different challenges. For example, the key challenge for forest carbon offsets is measuring additionality. For wetlands, a key challenge is defining a unit of measure for effectiveness. In general, the most serious problem facing offset programs is measuring whether the suggested environmental impacts are truly additional. There is a paucity of good data on this issue, and we think this situation is not likely to change anytime soon. While good administration of offset programs can lead to improvements in terms of lowering costs and possibly improving environmental outcomes, at some point, the inherent limitations of this policy instrument need to be recognized.

The design of offsets will often involve a tradeoff between cost savings and environmental quality. If regulators approve very few offsets because they set, say, a very stringent criteria for additionality, then there will likely be less room for manipulating baselines. But such criteria may leave out some offsetting activities that are desirable.

There is a need for more realistic empirical modeling of the impact of offsets. Many of the models of offsets that are used to assess costs savings and environmental impacts assume, for simplicity, that they will be implemented effectively. ${ }^{7}$ Yet, this does not appear to be the case based on our empirical assessment. Furthermore, the impact of offsets on government revenues and production of pollution-intensive goods also deserves more careful study. Modeling should also more closely reflect political realities. There is a need to model how key factors, including

\footnotetext{
${ }^{7}$ See, e.g., EPA's analysis of the Waxman-Markey climate bill (2009) or Resources for the Future's technical manual on a new national energy policy for the US (Resources for the Future 2010).
} 
voter support and the support of key interest groups, constrain the choice of policy instruments (Hahn 1990; Keohane et al. 1998).

In addition to examining the performance of some offset programs, we discussed the reasons why offsets are used. We believe offsets are probably best understood in terms of a political compromise regarding market-based approaches. Politicians wish to allow some flexibility in achieving an environmental outcome, but may be unwilling or unable to specify property rights completely. For example, in the case of climate change, the U.S. has only very imperfect control of sources of greenhouse gas emissions outside of its jurisdiction.

Combining the political economy of using offsets with their intrinsic design challenges raises a potentially serious problem - namely, that offsets may often fail to take adequate account of environmental or ecosystem damages. Because this problem may be significant, alternatives should be considered. One such alternative is to have a full-blown market-based regime, such as taxes or cap-and-trade used in their place, but this may not be feasible. A second is to require a form of compensation on a project-by-project basis that takes better account of social damages. This approach, however, may give rise to high transaction costs.

Our bottom line is that offsets are not a panacea, either in terms of promoting economic efficiency or ensuring a certain level of environmental quality. Still, we think in certain cases, they represent a reasonable approach for making environmental and economic progress on difficult challenges. The devil is frequently in the details, and these details need to be studied carefully before making an informed judgment about the likely effectiveness of particular offset programs. 


\section{References}

Australian Government - Department of Sustainability, Environment, Water, Population, and communities. 1999. Environment Protection and Biodiversity Conservation Act. http://www.environment.gov.au/epbc/index.html

Baumol, W. and W. Oates. 1988 The Theory of Environmental Policy. Second Edition, New York: Cambridge University Press

Bean, M., R. Kihslinger, and J. Wilkinson. 2008. Design of U.S. Habitat Banking Systems to Support the Conservation of Wildlife Habitat and At-Risk Species. Environmental Law Institute

Bertoldi, P. and T. Huld. 2006. Tradable certificates for renewabe electricity and energy savings. Energy Policy 34: 212-222

Bertoldi, P., S. Rezessy, O. Langniss and M. Vogt. 2005. White, Green and brown Certificates: How to make the most of them. ECEEE 2005 Summer Study. Paper \# 7203. http://www.eceee.org/conference_proceedings/eceee/2005c/Panel_7/7203bertoldi/

Brazil National Government. 2000. SNUG - National System for Conservation. http://www.icmbio.gov.br/sisbio/legislacao.php?id_arq=49 (Translated using Google translate)

Breetz, H.L. and K. Fisher-Vanden. 2007. Does Cost-Share Replicate Water Quality Trading Projects? Implications for a Possible Partnership. Review of Agricultural Economics 29.2: 201-215

Breetz, H.L., K. Fisher-Vanden, L. Garson, H. Jacobs, K. Kroetz, R. Terry. 2004. Water Quality Trading and Offset Initiatives in the US: A Comprehensive Survey. Dartmouth College

Bauch, S., E. Sills, L.C.E. Rodriguez, K. McGinley and F. Cubbage. 2009. Forest Policy Reform in Brazil. Journal of Forestry, Volume 107, Number 3: 132-138

Bushnell, J.B. 2010 The Economics of Carbon Offsets. NBER Working Paper 16305. http://www.nber.org/papers/w16305

Carr, C. and F. Rosembuj. 2008. Flexible Mechanisms for Climate Change Compliance: Emission Offset Purchases Under the Clean Development Mechanism. New York University Law Journal 16

Chadwick, B.P. 2006. Transaction Costs and the Clean Development Mechanism. Natural Resources Forum 30: 256-271

Cherry Creek Basin Water Quality Authority. 2009. 2008 Annual Report on Activities. http://www.cherrycreekbasin.org/pdf/2008AnnualReport.pdf

Cohen, L. R.G. Noll, eds. 1991. The Technology Pork Barrel. The Brokings Institution: Washington D.C.Colorado Department of Public Health and Environment. 2004. Colorado Pollutant Trading Policy. http://www.cdphe.state.co.us/wq/permitsunit/POLICYGUIDANCEFACTSHEETS/Polic yandGuidance/TradingPolicy.pdf

Crocker, T. D. 1966. 'The Structuring of Atmospheric Pollution Control Systems', in H. Wolozin, (ed.), The Economics of Air Pollution, New York: W.W. Norton \& Co

Dales, J. H. 1968. Pollution, Property and Prices, Toronto: University of Toronto Press Department of Environment and Conservation, Australia. 2005. Green Offsets for Sustainable Regional Development--ID16: Final Report. 
de Sepibus, J. 2008. Linking the EU Emissions Trading Scheme to JI, CDM, and post-2012 International Offsets: A Legal Analysis and Critique of the EU ETS and the Proposals for its Third Trading Period. NCCR Working Paper 2008/18

Dutschke, M. 2000. Host Country Driven Implementation--The Case of Costa Rica. A. Michaelowa and M. Dutschke (eds.). Climate Policy and Development: Flexible Instruments and Developing Countries. Edward Elgar Publishing. Cheltenham, UK

Ellerman, A.D. and B.K. Buchner 2007. The European Union Emissions Trading Scheme: Origins, Allocation, and Early Results. Review of Environmental Econconomics and Policy. Vol. 1, Issue 1: 66-87

Ellis, J., H. Winkler, J. Corfee-Morlot, and F. Gagnon-Lebrun. 2007. CDM: Taking Stock and Looking Forward. Energy Policy: 15-28

Electric Reliability Council of Texas. 2010. ERCOT'S 2009 Annual Report on The Texas Renewable Energy Credit Trading Program. Link at http://apps3.eere.energy.gov/greenpower/buying/customers.shtml?page=1\&companyid=8 23

Environmental Law Institute. 2007. Mitigation of Impacts to Fish and Wildlife Habitat:

Estimating Costs and Identifying Opportunities.Environmental Protection Agency (EPA). Environmental Law Institute. Website http://www.epa.gov/owow/watershed/trading/tradingfaq.html

Environmental Protection Agency (EPA). 2008a. Water Quality Trading Evaluation: Final Report

Environmental Protection Agency (EPA). 2008b. Renewable Energy Certificates. http://www.epa.gov/grnpower/documents/gpp_basics-recs.pdf

Environmental Protection Agency (EPA). 2009. Analysis of the American Clean Energy and Security Act of 2009 H.R. 2454 in the 111th Congress. http://www.epa.gov/climatechange/economics/economicanalyses.html\#hr2454

EuroWhiteCert Project. 2007. White Certificates: Concepts and Market Experiences. http://www.ewc.polimi.it/documents/EWC_brochure.pdf

European Commission. 2000. Managing Natura 2000 Sites: The provisions of Article 6 of the 'Habitats" Directive 92/43/EEC. Luxembourg: European Communities

European Commission. 2009. Natura 2000. Fact Sheet. http://ec.europa.eu/environment/nature/info/pubs/docs/nat2000/factsheet en.pdf

Fang, F., W. Easter, and P.L. Brezonik. 2005. Point-Nonpoint Source Water Quality Trading: A Case Study in the Minnesota River Basin. Journal of the American Water Resources Association, June: 645-658

Figueres, C. 2006. Sectoral CDM: Opening the CDM to the Yet Unrealized Goal of Sustainable Development. International Journal of Sustainable Development Law and Policy 6: 5-25.

Ferraz, C.F., 2003. Institutional Solutions for the Financing of Protected Areas in Brazil. Presented at the Fifth World Parks Congress, Sustainable Finance Stream, Durban, South Africa, September 2003. http://www.brazilink.org/tiki-download_file.php?fileId=195

Fox, J. and A. Nino-Murcia. 2005. Status of Species Conservation Banking in the United States. Conservation Biology: 996-1007

Goulder, L.H., I.W.H. Parry, R.C. Williams and D. Burtraw. 1999. The Cost-Effectiveness of Alternative Instruments for Environmental Protection in a Second-Best Setting. Journal of Public Economics 72: 329-360 
Government of Alberta, 2009. Technical Guidance for Offset Project Developers. http://environment.alberta.ca/documents/Technical-Guidance-for-Offset-ProjectDevelopers.pdf

Greiner, S. and A. Michaelowa. 2003. Defining Investment Additionality for CDM ProjectsPractical Approaches. Energy Policy 31: 1007-1015

Grubb, M., T. Laing, T. Counsell, W. Catherine 2009. Global carbon mechanisms: lessons and implications. Climatic Change. DOI: 10.1007/s10584-009-9791-z

Haddad, B. and J. Palmisano. 2001. Market Darwinism vs. market creationism: adaptability and fairness in the design of greenhouse gas trading mechanisms. International Environmental Agreements: Politics, Law and Economics, Vol. 1: 427-446

Hahn, R.W. 1989. Economic Prescriptions for Environmental Problems: How the Patient Followed the Doctor's Orders, The Journal of Economic Perspectives. Vol. 3, No. 2: 95114

Hahn, R.W. 1990. The political economy of environmental regulation: Towards a unifying framework. Public Choice. 65: 21-47

Hahn, R.W. and G.L. Hester. 1989. Where Did All the Markets Go? An Analysis of EPA's Emissions Trading Program. Yale Journal on Regulation 6.1: 109-153

Hahn, R.W. and Stavins, R.N., 1999. What Has the Kyoto Protocol Wrought? The Real Architecture of International Tradable Permit Markets. Washington, DC: American Enterprise Institute Press

He, G. and R.K. Morse. 2010. Making Carbon Offsets Work in The Developing World: Lessons from The Chinese Wind Controversy. Stanford University, Program on Energy and Sustainable Development. Working Paper \#90

Hepburn, C. 2007. Carbon Trading: A Review of the Kyoto Mechanisms. Annual Review of Environment and Resources 32: 375-393

Hoeltje, S.M. and C.A. Cole. 2007. Losing Function Through Wetland Mitigation in Central Pennsylvania, USA. Environmental Management 39: 385-402

Holt, E. And L. Bird. 2005. Emerging markets for renewable energy certificates: opportunities and challenges. National Renewable Energy Laboratory, Technical Paper 620-37388. http://citeseerx.ist.psu.edu/viewdoc/download?doi=10.1.1.121.1028\&rep=rep1\&type=pdf

Horan, R.D. 2002. Point-Nonpoint Nutrient Trading in the Susquehanna River Basin. Water Resources Research 38, 8

Hough, P. and M. Robertson. 2009. Mitigation under Section 404 of the Clean Water Act: Where it Comes From, What it Means. Wetlands Ecological Management 17: 15-33

Keiser \& Associates. 2004. Preliminary Economic Analysis of Water Quality Trading Opportunities in the Great Miami River Watershed, Ohio: Executive Summary.

Keiser, M.S. and A.F. Fang. 2005. Water Quality Trading in the United States: An Overview. Ecosystem Marketplace. http://www.ecosystemmarketplace.com/pages/dynamic/ article.page.php?page_id=3954\& section=home\&eod=1

Keohane, N.O., R.L. Revesz, R.N. Stavins, 1998. Choice of Regulatory Instruments in Environmental Policy. Harvard Environmental Law Review. Vol. 22. No. 2

Kettlewell, C.I., V. Bouchard, D. Porej, M. Micacchion, J.J. Mack, D. White, and L. Fay. 2008. An Assessment of Wetland Impacts and Compensatory Mitigation in the Cuyahoga River Watershed, Ohio, USA. Wetlands 28: 57-67

Kihslinger, R.L. 2008. Success of Wetland Mitigation Projects. National Wetlands Newsletter 30: $14-16$ 
King, D.M. and P.J. Kuch. 2003. Will Nutrient Credit Trading Ever Work? An Assessment of

Supply and Demand Problems and Institutional Obstacles. Environmental Law Reporter.

Klassen, G. and A Nentjes. 1995. Emission Trading for Air Pollution Control in Practice.

International Institute for Applied Systems Analysis Working Paper : WP-95-21

Kollmuss, A., M. Lazarus, C. Lee and C. Polycarp. 2008. A Review of Offset Programs: Trading Systems, Funds, Protocols, Standards and Retailers. Version 1.1. Stockholm: Stockholm Environmental Institute

Kossoy, A. and P. Ambrosi. 2010. State and Trends of the Carbon Market 2010. The World Bank. Washington D.C.

Krey, M. 2005. Transaction costs of Unilateral CDM Projects in India-Results from an Empirical Survey. Energy Policy 33:2385-2397

Lees, E. 2007. European Experience of White Certificates. World Energy Council and Ademe http://www.worldenergy.org/documents/white_certificate.pdf

Liroff, R. A. (1980), Air Pollution Offsets: Trading, Selling and Banking. Washington, DC: The Conservation Foundation

Liroff, R.A. 1986. Reforming Air Pollution Regulation: The Toil and Trouble of EPA's Bubble, Washington, DC: The Conservation Foundation

Liu, X. 2010. Extracting the resource rent from the CDM projects: Can the Chinese Government do better? Energy Policy, 38(2):1004-1009. DOI: 10.1016/j.enpol.2009.10.052

Matthews, J.W. and A.G. Endress. 2008. Performance Criteria, Compliance Success, and Vegetation Development in Compensatory Mitigation Wetlands. Environmental Management 41: 130-141

Michaelowa, A., Hayashi, D. and M. Marr 2009.Challenges for energy efficiency improvement under the CDM - the case of energy-efficient lighting, Energy Efficiency, 2, 4: 353-367

Michaelowa, A. and F. Jotzo. 2003. Impacts of transaction costs and institutional rigidities on the share of the Clean Development Mechanism in the global greenhouse gas market. Paper for the "Sitzung des Ausschusses Umweltökonomie im Verein für Socialpolitik". Rostock

Michaelowa, A. and F. Jotzo. 2005. Transaction costs, Institutional Rigidities, and the Size of the Clean Development Mechanism. Energy Policy 33: 511-523

Montero, J.P. 2000. Optimal design of a phase-in emissions trading program. Journal of Public Economics. 75: 273-291

Montgomery County Government. 2005. Enhanced Farmland Preservation Initiatives Overview. Montgomery County Government

Morgan, C. and A. Wolverton. 2005. Water Quality Trading in the United States. National Center for Environmental Economics Working Paper \#05-07

New Zealand Ministry for the Environment. 2009. An Everyday Guide to the Resource Management Act Series http://www.mfe.govt.nz/publications/rma/everyday/

North Carolina Division of Water Quality. 2010. Nonpoint Source Management Program: TarPamlico Nutrient Strategy. http://portal.ncdenr.org/web/wq/ps/nps/tarpamlico

NRDC. 2001.. Montgomery County Agricultural Reserve: The Countries Largest Farmland Protection Program. http://www.nrdc.org/cities/smartgrowth/solve/mont.asp

Olsen, K.H. 2007. The clean development mechanism's contribution to sustainable development: a review of the literature. Climatic Change. Volume 84, Number 1, 59-73, DOI: $10.1007 / \mathrm{s} 10584-007-9267-y$ 
Parry, I.W.H., and A.M. Bento. 2000. Tax Deductions, Environmental Policy, and the 'Double Dividend' Hypothesis. Journal of Environmental Economics and Management 39: 67-96 Policy Analysis in the Presence of Distorting Taxes

Parry, I.W.H., W.E. Oates. 2000. Policy Analysis in the Presence of Distorting Taxes. Journal of Policy Analysis and Management. Vol. 19, No. 4: 603-613

Pigou, A. C. 1920. The Economics of Welfare. London: Macmillan and Co.

Pollitt, M. 2010. "UK Renewable Energy Policy since Privatization.” Electricity Policy Research Group Working Paper 1002, University of Cambridge

Pruetz, R. and N. Standridge. 2009. "What Makes Transfer of Develpment Rights Work?" Journal of American Planning Association 75.1: 78-87

Quigley, J.T. and D.J. Harper. 2006. Compliance with Canada's Fisheries Act: A Field Audit of Habitat Compensation Projects. Environmental Management 37: 336-350

Resources for the Future and the National Energy Policy Institute. 2010. Toward a New National Energy Policy: Assessing the Options. Washington, DC: Resources for the Future.

Robertson, M.M. 2006. Emerging Ecosystem Services Markets: Trends in a Decade of Entrepreneurial Wetland Banking. Frontiers in Ecology and the Environment 4: 297302

Schneider, L. 2009. Assessing the Additionality of CDM Projects: Practical Experiences and Lessons Learned. Climate Policy 9: 242-254

Selman, M., S. Greenhalgh, E. Branosky, C. Jones, and J. Guiling. 2009. Water Quality Trading Programs: An International Overview. WRI Issue Brief. World Resources Institute, Washington, D.C.

Solomon, S., D. Qin, M. Manning, Z. Chen, M. Marquis, K.B. Averyt, M. Tignor and H.L. Miller (eds.). Contribution of Working Group I to the Fourth Assessment Report of the Intergovernmental Panel on Climate Change. Cambridge University Press, Cambridge, United Kingdom and New York, NY, USA

South Coast Air Quality Management District (SCAQMD). 2009. http://www.aqmd.gov/prdas/oldvehiclescrapping/mainpage.html

South Coast Air Quality Management District (SCAQMC). 2008. Rule 1610 Old-Vehicle Scrapping. http://www.aqmd.gov/rules/reg/reg16/r1610.pdf

Spieles, D.J. 2005. Vegetation Development in Created, Restored, and Enhanced Mitigation Wetland Banks of the United States. Wetlands 25: 51-63

State of Oregon Department of Environmental Quality. 2007. Water Quality Credit Trading in Oregon: A Case Study Report. Case Study. State of Oregon

State of Oregon Department of Environmental Quality. 2009. Water Quality Trading in NPDES Permits: Internal Management Directive. State of Oregon.State of Oregon Department of Environmental Quality. 2010. Water Quality Trading Fact Sheet. http://www.deq.state.or.us/wq/pubs/factsheets/programinfo/09-WQ012WQTradingIMD.pdf

Stavins, R.N. 2003. Experience with market-based environmental policy instruments in Handbook of Environmental Economics. Vol. 1. K.G. Mäler and J.Vincent eds. Amsterdam: Elsevier Science: 355-435

Ten Kate, K., J. Bishop and R. Banyon. 2004. Biodiversity Offsets: Views, Experience, and the Business Case. IUCN, Gland, Switzerland

Tietenberg, T. 2006. Environmental and Natural Resource Economics. 7th edition. Reading: Mass: Addison Wesley 
Tietenberg, T. and L. Lewis. 2008. Environmental \& Natural Resource Economics (8th Edition). Addison Wesley, Massachusetts

UNEP. 2010. The UNEP Risoe Centre on Energy, Climate and Sustainable Development. http://cdmpipeline.org/

UNFCCC. 1998. Kyoto protocol to the united nations framework Convention on climate change. http://unfccc.int/resource/docs/convkp/kpeng.pdf

UNFCCC. 2010a. http://cdm.unfccc.int/Statistics/index.html as of November 8, 2010

UNFCCC. 2010b. Clean Development Mechanism Validation and Verification Manual (Version 1.2). EB 55 Report, Annex 1

United States Government Accountability Office (GAO). 2005. Wetlands Protection: Corps of Engineers Does Not Have an Effective Oversight Approach to Ensure That Compensatory Mitigation is Occurring. Report to the Ranking Democratic Member, Committee of Transportation and Infrastructure, House of Representatives.

Victor, D.G. 2010. The Politics and Economics of International Carbon Offsets. Draft, May 17, 2010

U.S. Fish and Wildlife Service. 2009. Conservation Banking: Incentives for Stewardship.

Victoria State EPA. 2008. "Environmental Offsets." Discussion Paper 1202. 3 June 2008

Wara, M.W. 2008. Measuring the Clean Development Mechanism's Performance and Potential. UCLA Law Review 1759

Wara, M.W. and D.G. Victor. 2008. A Realistic Policy on International Carbon Offsets. Program on Energy and Sustainable Development, Working Paper \#74

Western Australia Environmental Protection Agency. 2006. "Environmental Offsets: Position Statement No. 9."

Wood, E. 2007. Green Trading: Why the case is on for US RECs?. Renewable Energy World. May 1, 2007: 67-75

Woodward, R.T., R.A. Kaiser, and A.M.B. Wicks. 2002. The Structure and Practice of Water Quality Trading Markets. Journal of the American Water Resources Association: 967979 


\begin{tabular}{|c|c|c|}
\hline Core Program & Offset Provisions & Description \\
\hline \multicolumn{3}{|l|}{ Greenhouse Gases } \\
\hline Kyoto Protocol & $\begin{array}{l}\text { Clean Development Mechanism (2000-) } \\
\text { Joint Implementation (2008-) }\end{array}$ & $\begin{array}{l}\text { The CDM provides a mechanism for Annex } 1 \text { and non-Annex } 1 \text { countries (which do not have capped emissions) to cooperate on } \\
\text { emissions reductions projects in non-Annex } 1 \text { countries. }\end{array}$ \\
\hline $\begin{array}{r}\text { UN Framework Convention on Climate } \\
\text { Change }\end{array}$ & Activities Implemented Jointly (1999-) & Provides a pilot phase for jointly implemented projects under the UNFCCC \\
\hline $\begin{array}{r}\text { Alberta Climate Change and Emissions } \\
\text { Management Act }\end{array}$ & Offset Credit System (2007-) & Firms can make reductions directly for Alberta CCEMA, use offset credits, or make payments to a fund. \\
\hline \multicolumn{3}{|l|}{ Air Quality } \\
\hline U.S. Clean Air Act & $\begin{array}{l}\text { Offsets Provisions, Clean Air Act } \\
\text { Amendments of } 1977 \text { (1977 - ) }\end{array}$ & $\begin{array}{l}\text { New sources moving into a nonattainment area must first control emissions to greatest degree possible and then more than offset } \\
\text { new emissions with reductions from regulated existing sources. }\end{array}$ \\
\hline $\begin{array}{l}\text { South Coast Air Quality Management } \\
\text { District Regulations(California) }\end{array}$ & 1610 Car Scrappage Program ( (1993 - ) & $\begin{array}{l}\text { For scrapping older, polluting cars, parties receive Mobile Source Emissions Reductions Credits . used to comply with core regulations } \\
\text { limiting emissions. }\end{array}$ \\
\hline \multicolumn{3}{|l|}{ Water Quality } \\
\hline $\begin{array}{r}\text { Protection of Environmental Operations } \\
\text { Act } 1997 \text { (New South Wales, Australia) }\end{array}$ & $\begin{array}{l}\text { Green Offsets for Sustainable } \\
\text { Development }(2003-2005)\end{array}$ & Allows new development projects to offset their salinity and nutrient impacts with offsite projects. \\
\hline U.S. Clean Water Act, NPDES & $\begin{array}{l}\text { Point-nonpoint source trading - Cherry } \\
\text { Creek, Colorado (1997-) }\end{array}$ & $\begin{array}{l}\text { Allows point source dischargers credit for "storm water controls and phosphorus removal technologies that go beyond baseline } \\
\text { BMPs." }\end{array}$ \\
\hline U.S. Clean Water Act, NPDES & $\begin{array}{l}\text { Impact offset provisions - Oregon } \\
\text { Revised Statute (2002-) }\end{array}$ & Mechanism for point source emitters to offset their water pollution, including temperature, as part of the permit writing process. \\
\hline U.S. Clean Water Act, NPDES & $\begin{array}{l}\text { Tar-Pamlico Nutrient Program, North } \\
\text { Carolina (1990-) }\end{array}$ & $\begin{array}{l}\text { Point source emitters of nutrients can purchase credits from the state administered NC Agriculture Cost Share Program, which uses } \\
\text { the revenue to cost share BMPs. }\end{array}$ \\
\hline \multicolumn{3}{|r|}{ e } \\
\hline $\begin{array}{r}\text { EU Directive of Energy End Use Efficiency } \\
\text { and Energy Services }\end{array}$ & $\begin{array}{l}\text { White certificates, Italian National Energy } \\
\text { Efficiency Plan 2007(2005-) }\end{array}$ & $\begin{array}{l}\text { Companies can meet their efficiency improvement requirements with in-house energy projects with their own customers or they can } \\
\text { contract with third parties to produce the reductionsbuy White Certificates on the open market, or pay a fee of } € 100 / \text { toe. }\end{array}$ \\
\hline $\begin{array}{r}\text { Texas Senate Bill } 7 \text { (1999): Texas Electric } \\
\text { Restructuring Act and Senate Bill } 20 \\
(2005)\end{array}$ & $\begin{array}{l}\text { Renewable Energy Certificates Provisions } \\
\text { of Texas Utilities Code (2001-) }\end{array}$ & $\begin{array}{l}\text { Firms that do not meet their renewable obligations can purchase renewable energy credits (RECs) earned by other generators for } \\
\text { their renewable energy generation capacity. }\end{array}$ \\
\hline European Renewable Energy Directive & $\begin{array}{l}\text { UK Renewables Obligation Certificate } \\
(2002-)\end{array}$ & $\begin{array}{l}\text { Individual electricity suppliers required to increase renewable energy to } 15.4 \% \text { of supply can meet part of obligation by buying ROCs } \\
\text { or paying a buyout price. }\end{array}$ \\
\hline
\end{tabular}




\begin{tabular}{|c|c|c|}
\hline Core Program & Offset Provisions & Description \\
\hline \multicolumn{3}{|l|}{ Habitat and Biodiversity } \\
\hline Canadian Fisheries Act & $\begin{array}{l}\text { Policy for the Management of Fish Habitat } \\
(1976-)\end{array}$ & Ensures "no net loss" of productive fish capacity by requiring developers to offset any negative impact on fish habitat. \\
\hline U.S. Clean Water Act, Section 404 & $\begin{array}{l}\text { Joint US EPA -Army Corps of Engineers } \\
\text { Memorandum of Agreement (1990) } \\
(1975-)\end{array}$ & $\begin{array}{l}\text { Project developers can offset residual damages to wetlands by (1) directly undertaking mitigation projects, (2) purchasing credits } \\
\text { from a mitigation bank, or (3) making "in-lieu" payments to a mitigation sponsor }\end{array}$ \\
\hline U.S. Endangered Species Act & Conservation Banking (1995-) & $\begin{array}{l}\text { Project developers can meet mitigation requirements under the ESA through projects aimed at conservation of rare species or } \\
\text { habitat. }\end{array}$ \\
\hline New Zealand Resource Management Act & Section 108(2) Resource offsets (1991-) & $\begin{array}{l}\text { To offset damage to natural resources, authorities can require: financial contribution, bond, or "protection, restoration, or } \\
\text { enhancement" of the natural environment }\end{array}$ \\
\hline $\begin{array}{r}\text { Brazil National System of Conservation } \\
\text { Units }\end{array}$ & Article 36 conservation units & $\begin{array}{l}\text { Requires that any project that involves environmental licensing and will have significant environmental impacts (as determined by an } \\
\text { environmental impact assessment) must use funds to maintain and develop conservation units of integral protection. Funds are set } \\
\text { by the licensor but cannot be less than } 0.5 \text { percent of the costs of the planned project.. }\end{array}$ \\
\hline $\begin{array}{r}\begin{array}{r}\text { Australia Environmental Protection and } \\
\text { Biodiversity Act }\end{array}\end{array}$ & Victoria Vegetative Offsets (1999-) & Actions that are likely to have a negative impact on native vegetation are required to offset losses through vegetation projects. \\
\hline $\begin{array}{r}\text { Montgormery County, Maryland, USA, } \\
\text { Master Plan, }\end{array}$ & Transferable Development Rights (1980-) & $\begin{array}{l}\text { "Sending sites" that have been designated for protection of green space can create "transferable development rights" and sell those } \\
\text { to "receiving sites" that acquire the right to exceed baseline development densities. }\end{array}$ \\
\hline $\begin{array}{r}\text { European Union1979 Birds Directive } \\
\text { 79/409/EEC; } 1992 \text { Habitats Directive } \\
92 / 43 / \mathrm{EEC}\end{array}$ & $\begin{array}{l}\text { Compensatory Measures on Natura } 2000 \\
\text { Network }\end{array}$ & $\begin{array}{l}\text { For protected areas under the Natura } 2000 \text { network of special protected areas projects that involve residual damage to the Natura } \\
\text { areas, Member countries are required to undertake compensatory measures to offset the negative impacts. }\end{array}$ \\
\hline \multicolumn{3}{|c|}{ References } \\
\hline \multicolumn{3}{|c|}{$\begin{array}{l}\text { UNFCCC (2009), Hahn and Hester (1989), SCAQMD (2009), Carbon Offset Research \& Education, EPA Website, Department of Environment and Conservation, Australia (2005), Breetz and Fisher-Vanden (2007), State of Oregor } \\
\text { Department of Environmental Quality. (2007), State of Oregon Department of Environmental Quality (2009), EuroWhiteCert Project (2007), Environmental Protection Agency (2008), Bertoldi et al. (2005), Quigley and Harper } \\
\text { (2006), Environmental Law Institute (2007), Bean et al. (2008), U.S. Fish and Wildlife Service (2009), Fox and Nino-Murcia (2005), New Zealand Ministry for the Environment (2009), Ferraz (2003), Bauch et al. (2009), Brazil } \\
\text { National Government (2000), Australian Government - Department of Sustainability, Environment, Water, Population, and communities (1999), Montgomery County Government (2005), European Commission (2000), } \\
\text { European Commission (2009) }\end{array}$} \\
\hline
\end{tabular}




\begin{tabular}{|c|c|c|c|c|c|c|c|c|}
\hline Core Program & $\begin{array}{l}\text { Equivalency } \\
\text { Approach }\end{array}$ & Ex-ante Offset Certification Requirement & $\begin{array}{l}\text { Definition of } \\
\text { Units }\end{array}$ & $\begin{array}{l}\text { Offset Reference } \\
\text { Case }\end{array}$ & $\begin{array}{l}\text { Ex post Offset } \\
\text { Measurement }\end{array}$ & Leakage & $\begin{array}{l}\text { Trading } \\
\text { Ratio } \\
\text { Offset } \\
\text { /Impact }\end{array}$ & $\begin{array}{l}\text { Form of } \\
\text { Reward }\end{array}$ \\
\hline \multicolumn{9}{|l|}{ Greenhouse Gases } \\
\hline $\begin{array}{r}\text { Kyoto Protocol, Clean } \\
\text { Development Mechanism }\end{array}$ & $\begin{array}{l}\text { Demonstrated } \\
\text { equivalency }\end{array}$ & $\begin{array}{l}\text { Output - project developers must demonstrate that the } \\
\text { proposed project can be evaluated with either an established } \\
\text { evaluation method that has been approved by the CDM } \\
\text { Executive or propose a method for approval. }\end{array}$ & $\begin{array}{l}\text { Tonnes of } \\
\mathrm{CO}_{2} \\
\text { equivalents }\end{array}$ & $\begin{array}{l}\text { Business as usual - i.e., } \\
\text { the counterfactual }\end{array}$ & $\begin{array}{l}\text { Field } \\
\text { measurement and } \\
\text { self-reporting }\end{array}$ & $\begin{array}{l}\text { Project developers } \\
\text { must deduct } \\
\text { leakage which is } \\
\text { "measurable" and } \\
\text { "attributable" to } \\
\text { the project }\end{array}$ & 1.0 & $\begin{array}{l}\text { CERs (certified } \\
\text { emsissions } \\
\text { reductions) }\end{array}$ \\
\hline $\begin{array}{r}\text { UN Framework Convention } \\
\text { on Climate Change, } \\
\text { Activities Implemented } \\
\text { Jointly }\end{array}$ & $\begin{array}{l}\text { Demonstrated } \\
\text { equivalency }\end{array}$ & $\begin{array}{l}\text { Inputs - no formal certification, but countries claiming credit } \\
\text { for AIJ projects in their periodic national assessments must } \\
\text { submit a report for each AIJ project in a "Uniform Report } \\
\text { Format" providing a description of the project and its } \\
\text { quantitative assessment. }\end{array}$ & $\begin{array}{l}\text { Tonnes of } \\
\mathrm{CO}_{2} \\
\text { equivalents }\end{array}$ & $\begin{array}{l}\text { Historic, projected or } \\
\text { other; Uniform Report } \\
\text { Format requests } \\
\text { documentation of } \\
\text { financial additionality }\end{array}$ & $\begin{array}{l}\text { Project developer } \\
\text { designs and } \\
\text { reports } \\
\text { monitoring plan }\end{array}$ & $\begin{array}{l}\text { Uniform Report } \\
\text { Format states } \\
\text { "leakage shall be } \\
\text { addressed". }\end{array}$ & 1.0 & $\begin{array}{l}\text { Inclusion in } \\
\text { national } \\
\text { assessment } \\
\text { reports }\end{array}$ \\
\hline $\begin{array}{r}\text { Alberta Climate Change and } \\
\text { Emissions Management Act, } \\
\text { Offset Credit System }\end{array}$ & $\begin{array}{l}\text { Demonstrated } \\
\text { equivalency }\end{array}$ & $\begin{array}{l}\text { Output - requires offset project plan including methods for } \\
\text { quantification and monitoring }\end{array}$ & $\begin{array}{l}\text { Tonnes of } \\
\mathrm{CO}_{2} \\
\text { equivalents }\end{array}$ & $\begin{array}{l}\text { As proposed by offset } \\
\text { developer }\end{array}$ & $\begin{array}{l}\text { As stipulated in } \\
\text { plan, with } 3^{\text {rd }} \\
\text { party verification }\end{array}$ & $\begin{array}{l}\text { Addressed, but no } \\
\text { standards }\end{array}$ & 1.0 & $\begin{array}{l}\text { "Alberta-based } \\
\text { offset credits" }\end{array}$ \\
\hline \multicolumn{9}{|l|}{ Air Quality } \\
\hline $\begin{array}{r}\text { U.S. Clean Air Act, Offsets } \\
\text { Provisions }\end{array}$ & $\begin{array}{l}\text { Demonstrated } \\
\text { equivalency }\end{array}$ & $\begin{array}{l}\text { Inputs - demonstration of reduction in existing sources below } \\
\text { permitted levels }\end{array}$ & $\begin{array}{l}\text { Tonnes of } \\
\mathrm{SO}_{2}\end{array}$ & $\begin{array}{l}\text { Compliance with } \\
\text { permitted emissions } \\
\text { levels by offsetting } \\
\text { entity }\end{array}$ & None & Not applicable & $1.0-1.2$ & $\begin{array}{l}\text { Permit for new } \\
\text { source }\end{array}$ \\
\hline $\begin{array}{r}\text { California SCAQMD, } 1610 \\
\text { Car Scrappage Program }\end{array}$ & $\begin{array}{l}\text { Deemed } \\
\text { equivalency }\end{array}$ & Inputs - Inspection fo retired car and certification of removal & $\begin{array}{l}\text { Tonnes of } \\
\mathrm{SO}_{2}\end{array}$ & $\begin{array}{l}>3 \text { years of car } \\
\text { operation }\end{array}$ & None & Not addressed & $1.0-1.2$ & $\begin{array}{l}\text { Mobile source } \\
\text { emissions } \\
\text { reduction credit }\end{array}$ \\
\hline \multicolumn{9}{|l|}{ Water Quality } \\
\hline $\begin{array}{r}\text { New South Wales, Australia } \\
\text { Green Offsets for } \\
\text { Sustainable Development }\end{array}$ & $\begin{array}{l}\text { Negotiated } \\
\text { equivalency }\end{array}$ & Inputs - modelled results and implementation of project & $\begin{array}{l}\text { Tonnes of } \\
\text { salt per year }\end{array}$ & $\begin{array}{l}\text { Historical land use } \\
\text { patterns }\end{array}$ & $\begin{array}{l}\text { Ambient } \\
\text { measures by } \\
\text { offset project, } \\
\text { regulator } \\
\text { inspection }\end{array}$ & Not applicable & 1.5 & $\begin{array}{l}\text { License to } \\
\text { operate }\end{array}$ \\
\hline $\begin{array}{r}\text { Cherry Creek Basin Water } \\
\text { Quality Authority, Colorado } \\
\text { Point-nonpoint source } \\
\text { trading }\end{array}$ & $\begin{array}{l}\text { Negotiated } \\
\text { equivalency }\end{array}$ & Inputs - modelled results and implementation of project & $\begin{array}{l}\text { Pounds of } \\
\text { phosphorus } \\
\text { per year }\end{array}$ & Standard BMPs in place & $\begin{array}{l}\text { Ambient } \\
\text { measures by state } \\
\text { agency }\end{array}$ & Not addressed & $1.3-3.0$ & $\begin{array}{l}\text { Phosphorus } \\
\text { credits }\end{array}$ \\
\hline $\begin{array}{r}\text { Oregon impact offset } \\
\text { provisions } \\
\end{array}$ & $\begin{array}{l}\text { Demonstrated } \\
\text { equivalency }\end{array}$ & Inputs - modelled results and implementation of project & Kcal per day & Historic land use pattern & Field monitoring & Not addressed & 2.0 & Permit issuance \\
\hline $\begin{array}{r}\text { North Carolina, Tar- } \\
\text { Pamlico Nutrient Program }\end{array}$ & $\begin{array}{l}\text { Demonstrated } \\
\text { equivalency }\end{array}$ & Outputs - state as sole developer and supplier of offset credits & $\begin{array}{l}\text { Kilograms } \\
\text { nitrogen and } \\
\text { phosphorus } \\
\text { per year } \\
\end{array}$ & $\begin{array}{l}\text { Standard practices } \\
\text { without BMPs }\end{array}$ & $\begin{array}{l}\text { Monitoring of } \\
\text { activities }\end{array}$ & Not addressed & 2.1 & $\begin{array}{l}\text { Compliance } \\
\text { certification }\end{array}$ \\
\hline \multicolumn{9}{|l|}{ Energy } \\
\hline $\begin{array}{r}\text { Italian White Certificate } \\
\text { Program }\end{array}$ & $\begin{array}{l}\text { Deemed and } \\
\text { Demonstrated } \\
\text { equivalency }\end{array}$ & Inputs - adoption of approved or modelled technology & $\begin{array}{l}\text { Tons of oil } \\
\text { equivalents }\end{array}$ & $\begin{array}{l}\text { Current practices - } \\
\text { national averages }\end{array}$ & $\begin{array}{l}\text { Random audit of } \\
\text { inputs }\end{array}$ & $\begin{array}{l}\text { Potential } \\
\text { "rebound" effect } \\
\text { not addressed }\end{array}$ & 1.0 & $\begin{array}{l}\text { Tradable } \\
\text { certificate }\end{array}$ \\
\hline $\begin{array}{r}\text { Texas Renewable Energy } \\
\text { Certificates }\end{array}$ & $\begin{array}{l}\text { Demonstrated } \\
\text { equivalency }\end{array}$ & Output - renewable electricity generated & $\begin{array}{l}\text { Megawatt- } \\
\text { hours }\end{array}$ & $\begin{array}{l}\text { Any new renewable } \\
\text { counts }\end{array}$ & $\begin{array}{l}\text { Metered } \\
\text { generation }\end{array}$ & Not addressed & 1.0 & $\begin{array}{l}\text { Renewable } \\
\text { energy } \\
\text { certificate }\end{array}$ \\
\hline $\begin{array}{r}\text { UK Renewables Obligation } \\
\text { Certificate }\end{array}$ & $\begin{array}{l}\text { Quantitative } \\
\text { equivalency }\end{array}$ & Output - renewable electricity generated & $\begin{array}{l}\text { Megawatt- } \\
\text { hours }\end{array}$ & $\begin{array}{l}\text { Any new renewable } \\
\text { counts }\end{array}$ & $\begin{array}{l}\text { Metered } \\
\text { generation }\end{array}$ & Not addressed & $0.5-4.0$ & $\begin{array}{l}\text { Renewable } \\
\text { obligation } \\
\text { certificate }\end{array}$ \\
\hline
\end{tabular}




\section{Table 2: Design Features of Offset Programs, continued}

\begin{tabular}{|c|c|c|c|c|c|c|c|c|}
\hline Core Program & $\begin{array}{l}\text { Equivalency } \\
\text { Approach }\end{array}$ & Ex-ante Offset Certification Requirement & Definition of Units & $\begin{array}{c}\text { Offset Reference } \\
\text { Case }\end{array}$ & Measurement & Leakage & $\begin{array}{l}\text { Trading Ratio } \\
\text { Offset /Impact } \\
\end{array}$ & $\begin{array}{l}\text { Form of } \\
\text { Reward }\end{array}$ \\
\hline \multicolumn{9}{|l|}{ Habitat and Biodiversity } \\
\hline $\begin{array}{r}\text { Canada Fisheries Act, } \\
\text { Habitat Provisions }\end{array}$ & $\begin{array}{l}\text { Negotiated } \\
\text { equivalency }\end{array}$ & $\begin{array}{l}\text { Inputs- based on professional judgment with } \\
\text { consideration of initial productive capacity of habitat, } \\
\text { habit requirements of affected fish species, proximity } \\
\text { to Native communities, and feasibility of building like } \\
\text { habitat nearby. }\end{array}$ & $\begin{array}{l}\text { Tonnes per year of } \\
\text { fish production } \\
\text { capacity }\end{array}$ & $\begin{array}{l}\text { Productive capacity } \\
\text { of habitat prior to } \\
\text { project. }\end{array}$ & $\begin{array}{l}\text { Inspection of } \\
\text { activity. }\end{array}$ & Not applicable & 1.0 & $\begin{array}{l}\text { Permit } \\
\text { issuance }\end{array}$ \\
\hline $\begin{array}{r}\text { U.S. Wetlands Mitigation } \\
\text { Banking }\end{array}$ & $\begin{array}{l}\text { Demonstrated } \\
\text { and negotiated } \\
\text { equivalency }\end{array}$ & Outputs - evaluated post construction & $\begin{array}{l}\text { Acres } x \text { scaling } \\
\text { points }\end{array}$ & No wetlands present & $\begin{array}{l}\text { Inspection for acres } \\
\text { and subjective } \\
\text { evaluation for } \\
\text { quality }\end{array}$ & Not applicable & $\begin{array}{l}1.0-2.0 \text { but varies } \\
\text { among wetland } \\
\text { types }\end{array}$ & $\begin{array}{l}\text { Wetlands } \\
\text { mitigation } \\
\text { credit }\end{array}$ \\
\hline $\begin{array}{r}\text { U.S. Endangered Species } \\
\text { Act, Conservation } \\
\text { Banking }\end{array}$ & $\begin{array}{l}\text { Demonstrated } \\
\text { equivalency }\end{array}$ & $\begin{array}{l}\text { Outputs - creation of an easement and improvements } \\
\text { (if any) on approved habitat }\end{array}$ & $\begin{array}{l}\text { Acres } x \text { species (e.g., } \\
\text { acres of San Jauquin } \\
\text { kit fox) }\end{array}$ & $\begin{array}{l}\text { Land use before set } \\
\text { aside }\end{array}$ & By inspection & Not addressed & $0.1-2.0$ & $\begin{array}{l}\text { Conservation } \\
\text { credits }\end{array}$ \\
\hline $\begin{array}{r}\text { New Zealand Resource } \\
\text { Management Act, } \\
\text { Resource Use Consent } \\
\text { Provisions }\end{array}$ & $\begin{array}{l}\text { Financial and } \\
\text { negotiated } \\
\text { equivalency }\end{array}$ & $\begin{array}{l}\text { Inputs - Professional judgment regarding compliance } \\
\text { with relevant sustainable management plans and } \\
\text { standards. }\end{array}$ & Dollars, other & $\begin{array}{l}\text { State of } \\
\text { environment before } \\
\text { resource use }\end{array}$ & None & $\begin{array}{l}\text { N/A; national } \\
\text { approach to } \\
\text { sustainable } \\
\text { development. }\end{array}$ & NA & $\begin{array}{l}\text { Permit } \\
\text { issuance }\end{array}$ \\
\hline $\begin{array}{r}\text { Brazil National System of } \\
\text { Conservation Units }\end{array}$ & $\begin{array}{l}\text { Negotiated } \\
\text { and financial } \\
\text { equivalency }\end{array}$ & $\begin{array}{l}\text { Inputs - creation of protected area or payment for } \\
\text { offset. }\end{array}$ & $\begin{array}{l}\text { Varied dimensions of } \\
\text { environmental } \\
\text { impacts }\end{array}$ & None & None & Not addressed & NA & $\begin{array}{l}\text { Issuance of } \\
\text { license }\end{array}$ \\
\hline $\begin{array}{r}\text { Victoria Vegetative } \\
\text { Offsets }\end{array}$ & $\begin{array}{l}\text { Negotiated } \\
\text { equivalency }\end{array}$ & $\begin{array}{l}\text { Inputs - Professional judgment regarding impacts of } \\
\text { project, provision of acceptable offset plan. }\end{array}$ & $\begin{array}{l}\text { Hectares x quality } \\
\text { scaling }\end{array}$ & $\begin{array}{l}\text { State of } \\
\text { environment before } \\
\text { resource use }\end{array}$ & None & Not applicable & $1.0-2.0$ & $\begin{array}{l}\text { Project } \\
\text { approval }\end{array}$ \\
\hline $\begin{array}{r}\text { Montgomery County, } \\
\text { Maryland Transferable } \\
\text { Development Rights }\end{array}$ & $\begin{array}{l}\text { Deemed } \\
\text { equivalency }\end{array}$ & $\begin{array}{l}\text { Creation of easement prohibiting development on rural } \\
\text { "sending area" }\end{array}$ & Housing units & Non easement & $\begin{array}{l}\text { Inspection to } \\
\text { confirm no } \\
\text { development }\end{array}$ & Not addressed & 0.2 & $\begin{array}{l}\text { Additional } \\
\text { housing unit } \\
\text { permits in } \\
\text { "receiving } \\
\text { area." } \\
\end{array}$ \\
\hline $\begin{array}{r}\text { Natura } 2000 \text { Network } \\
\text { Compensatory Measures }\end{array}$ & $\begin{array}{l}\text { Negotiated } \\
\text { equivalency }\end{array}$ & $\begin{array}{l}\text { Inputs - ex post award of permist following successful } \\
\text { development of negotiated "compensatory measures". }\end{array}$ & $\begin{array}{l}\text { Multiple measures of } \\
\text { biological value }\end{array}$ & $\begin{array}{l}\text { Pre-development } \\
\text { project state of } \\
\text { Natura } 2000 \text { sites }\end{array}$ & $\begin{array}{l}\text { Inspection of } \\
\text { project activities }\end{array}$ & Not applicable & 1.0 & $\begin{array}{l}\text { Project } \\
\text { approval }\end{array}$ \\
\hline
\end{tabular}

References

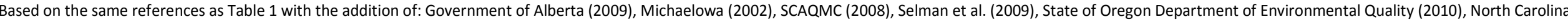

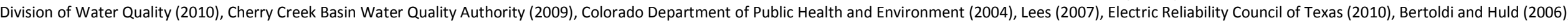

Pollitt (2010), Holt and Bird (2005), Wood (2007), Pruetz and Standridge (2009), NRDC (2001), Kihslinger (2008), Ten Kate et al. (2004), 
Figure 1: Setting the Baseline for Offset Suppliers

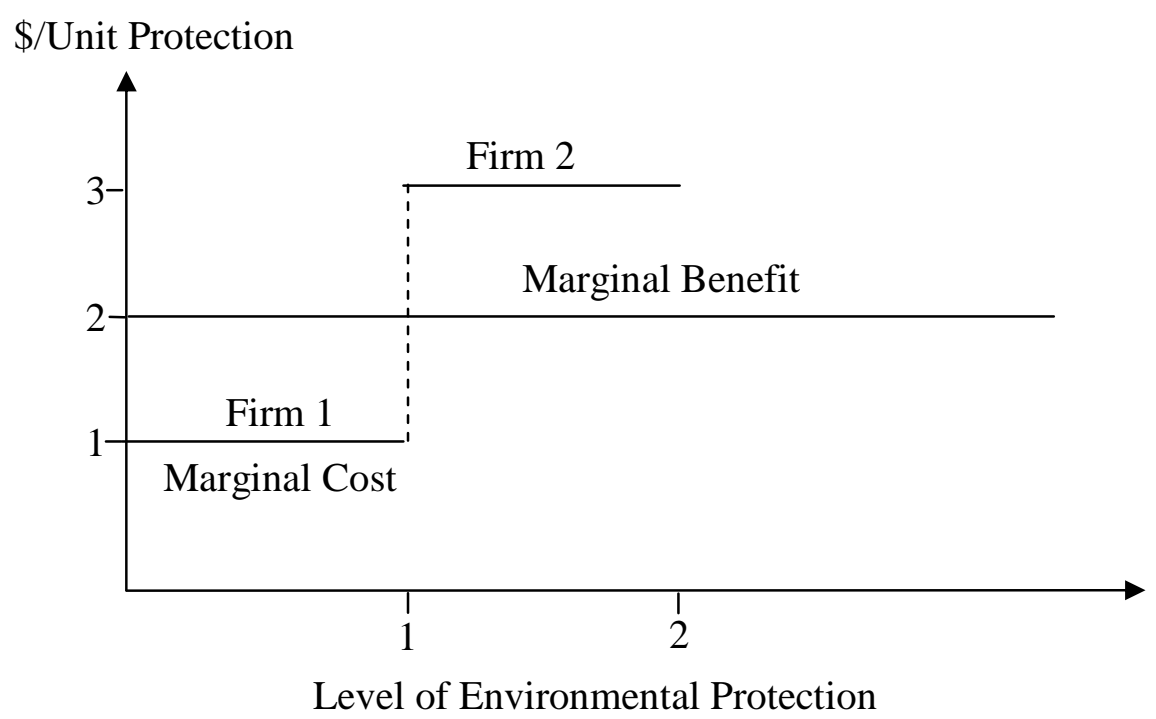


Figure 2

Accumulated certified emission reductions issued by sector

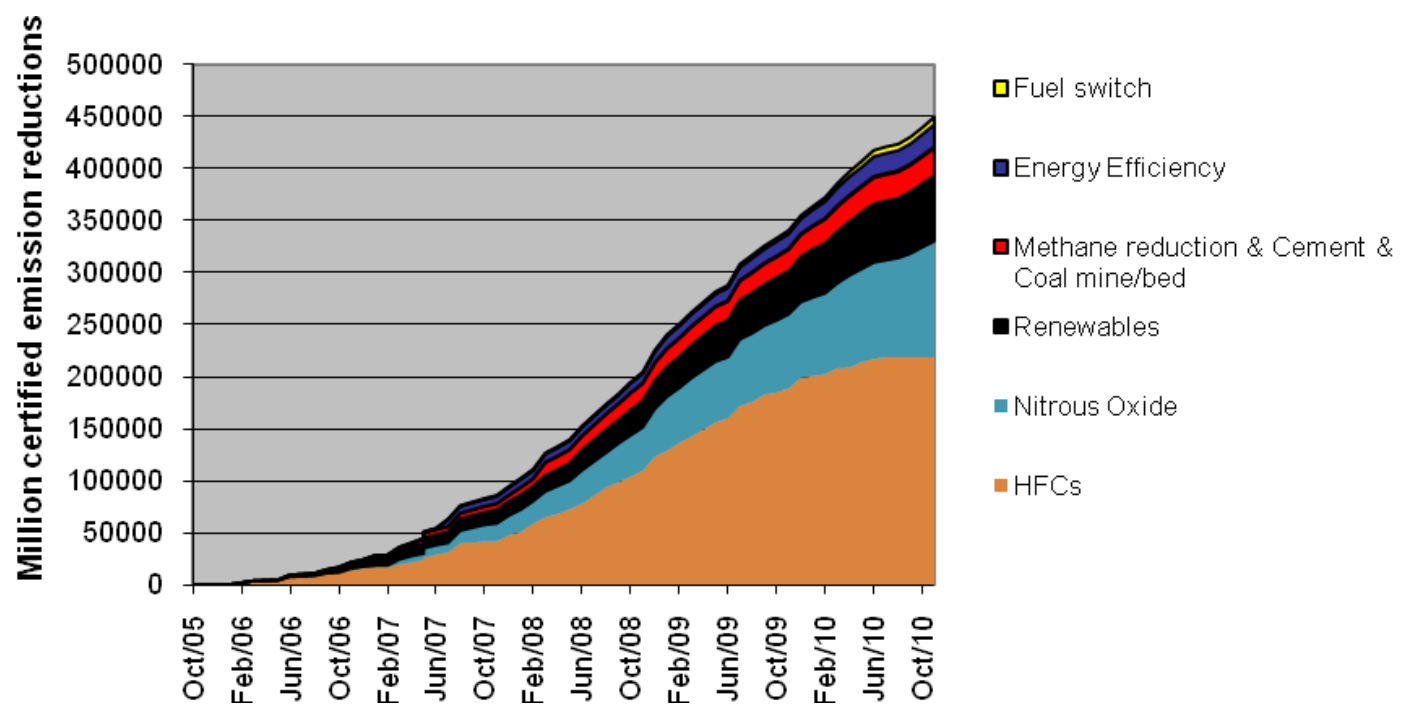

Source: (UNEP 2010) 


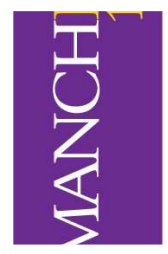

The University of Manchester

Sustainable Consumption Institute

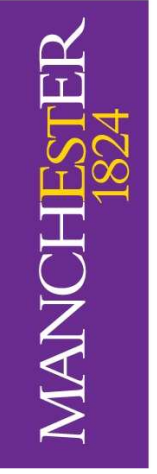

For more information please contact:

Sustainable Consumption Institute The University of Manchester

188 Waterloo Place

Oxford Road

Manchester, UK

M13 9PL

T: 01612754030

F: 01612750188

E: sci@manchester.ac.uk 